CIRJE-F-126

\title{
When are Judges and Bureaucrats Left Independent? \\ Theory and History from Imperial Japan, \\ Postwar Japan, and the United States
}

J. Mark Ramseyer

Harvard Law School

Eric B. Rasmusen

Indiana University / CIRJE

August 2001

Discussion Papers are a series of manuscripts in their draft form. They are not intended for circulation or distribution except as indicated by the author. For that reason Discussion Papers may not be reproduced or distributed without the written consent of the author. 
JUDICIAL INDEPENDENCE: ECONOMIC THEORY AND JAPANESE EMPIRICS J. Mark Ramseyer \& Eric B. Rasmusen

Ramseyer:
Harvard Law School, Cambridge, MA 02138
Email: Ramseyer@law.harvard.edu
(617) 497-4878 (off); (617) 497-6118 (fax)

$\underline{\text { Rasmusen: }}$

Indiana University, Kelley School of Business 1309 E. 10th Street, Bloomington, IN 47405-1701

Email: Erasmuse@indiana.edu (812) 855-9219 (off); (812)855-3354 (fax)

This is one chapter from the book, Judicial Independence: Economic Theory and Japanese Empirics, that Mark Ramseyer and Eric Rasmusen are writing. In preceding chapters we explain the institutions of modern Japan's judiciary and use regression analysis to test whether judges who rule in ways the ruling Liberal Democratic Party (the LDP) disliked were penalized in their careers. We find that they were for some kinds of cases-involving such things as the constitutionality of the military, injunctions against the national (but not local) government, reapportionment, and electioneering laws. They were not penalized for other kinds of cases - tax and criminal cases. Those results are drawn from our earlier published papers, reorganized and synthesized for the present book.

This chapter does not draw on our published work. It asks why the degree and type of independence of judges in modern Japan is different from that of other civil servants. In particular, we compare judges in modern Japan, pre-war Japan, and the United States; and we compare judges with other kinds of public employees, asking why they are not elected and why they are not directly under the control of politicians.

This chapter can be found at Http://Php.Indiana.edu/ erasmuse/papers/jbook/07Comparative.doc. The website for the book is at $\mathrm{Http}: / / \mathrm{Php}$. Indiana.edu/ erasmuse/papers/jbook/jbook.htm.

August 1, 2001

When are Judges and Bureaucrats Left Independent? Theory and History from Imperial Japan, Postwar Japan, and the United States

Our approach has been based on promotion of judges as an incentive scheme. Even if members of an organization cannot be expelled or have their salaries reduced, the possibility of promotion subjects them to the influence of whoever decides personnel policy. Carrots are just as much incentives as sticks; the withholding of a reward can be as effective as the infliction of a punishment. Thus, despite the rhetoric of independence, nations in whose courts judges 
start young and advance through the ranks depending on their talent and achievement have left a significant opening for political influence. We have found that in one of those nations, Japan, this structure has indeed produced politically skewed incentives.

On the one hand, the Japanese government offers parties to quarrels fiercely independent judges if the quarrel is private. It does so because independent judicial resolution of private disputes is a service voters demand of the politicians who can influence judges. On the other hand, when parties are locked in a dispute with the government, the calculus changes.

Independent judges for private disputes are part -- but only a part -- of the portfolio of policies and services for which voters elected the politicians. Suppose the majority party keeps judges rigorously independent of itself not just in private-law disputes, but in public-law ones too. If the personal preferences of judges diverge from those of the majority electorate, judges can use their independence to stymie the delivery of the majority's desired policies. As a result, where a dispute involves politically charged issues, judges must worry about more than just what they think the law says or what they would personally like to see happen.

To be sure, in some public-law disputes even Japanese politicians keep judges independent. In mundane administrative disputes, or in those involving local politicians who may be out of synch with national sentiment, they can and do use independent judges to help monitor their bureaucratic agents, as we have found in our statistical analysis of tax disputes. Those disputes seldom raise major issues of policy but often involve misbehaving bureaucrats. By helping to keep bureaucrats in line, independent judges in these disputes can help politicians deliver their promised services (McCubbins \& Schwartz, 1984). In ordinary criminal disputes too, majority politicians apparently subject their judges to unbiased incentives. And we do not contradict the conventional wisdom that Japanese politicians do not intervene directly and use crude methods such as giving direct commands as to how particular opinions should be written or firing judges who disagree with them. The political influence is more subtle.

A finding that Japanese politicians have erected a structure in which judges have some independence but still are vulnerable to indirect political influence, however, raises two comparative puzzles. First, why did those politicians choose a degree of judicial independence different from other politicians such as those of imperial Japan (1868-1945) or the federal government of the United States? Second, why do politicians anywhere make judges more independent than other kinds of bureaucrats?

First, under what circumstances will a ruling party give judges unbiased incentives in politically charged cases? When will it instead subject them to biased incentives or replace them outright? The usual bromides about making judges independent to protect "discrete and insular minorities" take us nowhere. Even in the United States., the most prominent examples of judicial protection of minorities turn out to involve minorities that are part of the coalition behind one of the principal political parties, as the Japanese-Americans discovered during World War II, and in Japan there has been both little supply of and little demand for this kind of minority protection. Hence we are left wondering in what circumstances majority party politicians will delegate discretion over decisions with serious electoral implications to judges they cannot constrain, and what means of control they will use if they decide not to delegate.

We suggest an answer from the fundamental principle of the theory of repeated games. In a Prisoner's Dilemma, rational players who expect to play the game only once will not refrain from taking advantage of each other in their choices. Players who expect to play the game with each other indefinitely, on the other hand, have incentive to cooperate if they think 
that will induce the other side to cooperate with them later. So too with whether rational politicians will keep their hands off of the courts. Fundamentally, whether they keep them independent - the analog to the cooperative strategy in the prisoner's dilemma -- depends on two things: (a) whether they expect elections to continue indefinitely, and (b) whether they expect to alternate with the other party in winning elections, if they do expect elections to continue. Only where the ruling party expects there to be future elections and believes it has a good chance of being in and out of power will it favor independent courts. And if the ruling party does not wish to keep courts independent, the method it uses will depend on the length of time it expects to survive before losing power. ${ }^{1}$

We will illustrate this argument through three examples: modern Japan (Section I), the federal courts of the United States (Section II), and imperial (1868-1945) Japan (Section III). In the United States, politicians expect the electoral system to continue, but no one gives either party high odds of controlling the government indefinitely. As a result, both parties have offered independent courts. In modern Japan, politicians expect competitive elections to continue indefinitely, but until recently those in the ruling LDP rationally expected to win every time. As a result, they offered less independent courts. Since they expected to keep winning, however, they could use the leisurely control method of indirect influence over judicial promotions, a method which helped retain the advantages of judicial independence in non-political disputes. In imperial Japan, none of the politicians could expect his party to always win elections, but none could expect the electoral system itself to continue either, and the threat to elections was not from the current ruling party but from the military. As a result, the ruling politicians had short time horizons, and offered less independent courts controlled by cruder methods. We outline this logic in Section IV. We then, in Section V, address the second of the comparative puzzles: why judiciaries are different from other bureaucracies.

Before we begin, however, a word of explanation may be helpful. We will speak of politicians choosing this and doing that with regard to policies and judges. This is often literally true, but even then it is a bit misleading. Politicians must pay attention to voters. In a competitive electoral regime, they must pay a lot of attention, and can usually be viewed as simply the tool of the electorate, with appropriate weight being given to those who spend more of their time or money on trying to elect particular politicians. Even in a less democratic regime such as Meiji Japan, politicians must pay some attention to the populace, since popular support is one element of their power. Moreover, constitutions are written by past politicians, influenced by past citizens, and not by present politicians. Thus, when we speak of choice of a constitution by politicians, we are really speaking of the choice past politicians made under the influence of the voters, and of the choice of present politicians and voters not to try to make an effort to change the constitution. Japan's LDP did not write or adopt the modern Japanese constitution or the parliamentary act which specified details of the judicial system-indeed, the LDP had not yet been created at the time. But the LDP did maintain the constitution and judiciary act, as part of the package it offered Japanese voters. And since LDP politicians are the ones who make the decisions, as the agents of the voters, it will be most convenient to phrase our discussion in terms of the choices of politicians.

\footnotetext{
${ }^{1}$ This argument can be found in Ramseyer (1994) and is modeled formally in Stephenson (2001), who draws attention to the importance of the parties' forward-lookingness and risk aversion and the judges' independent positions not being too extreme. Here, we will not rely on risk aversion, and we will subsume judges' independent positions under the general cost of not monitoring judges closely.
} 


\section{Modern Japan}

Japanese politicians in the LDP ruled Japan continuously from 1955 to 1993 . They did not hold power this long by chance. In part, they held it by providing median voter policies, aided by the reluctance of opposition Socialists and Communists to moderate their ideologies. In part too, they held it by rationally manipulating the institutional structure of government to their electoral advantage. In the process, they manipulated the judiciary as well.

The modern Japanese Constitution vests the "whole judicial power," in the courts. It bans other judicial institutions (Art. 76(a)) and gives parties to administrative disputes the right to appeal to the courts (Art. 76(b)). It further declares that "judges shall be independent in the exercise of their conscience and shall be bound by the Constitution and the laws" (Art. 76(c)). Although the Cabinet does appoint judges to the Supreme Court and lower courts, it cannot fire them at will. Instead, only the Diet can fire them, and only through impeachment (Art. 78). To impeach, the Diet must find that a judge grossly violated the standards of the office, neglected the duties of the job, or dishonored the institution of the courts. ${ }^{2}$ These articles and excerpts from the 1889 Japan and 1789 U.S. constitutions can be found in the Appendix at the end of this chapter.

Although Japanese judges have not been as independent as their American peers, ${ }^{3}$ the reason does not lie in any of the obvious institutional constraints. ${ }^{4}$ The Japanese Diet seldom impeaches judges. From 1948 to 1989, its Judicial Impeachment Committee received 5,700 impeachment complaints but ruled against the judges only 12 times. ${ }^{5}$ As noted in Chapter 1, Japanese voters have never expelled a Supreme Court justice in a retention vote, and the Japanese Cabinet rarely refuses to rehire a judge at the end of a ten-year term.

Instead, LDP leaders have controlled judges more subtly, through the job assignment process we have been studying in this book. They controlled assignments through the court's administrative office, the Supreme Court Secretariat. In turn, they controlled the Secretariat through the series of strategic moves we have explained earlier. First, in part because the Supreme Court formally controls the Secretariat, they appointed only loyal LDP partisans to the Supreme Court. Second, to ensure that their Supreme Court appointees did not change their views while in office, the LDP leaders appointed them late in life. As a result, Japanese Supreme Court justices served a mean of only six years before retiring at age seventy (ZSKS, 1990: 46870). Third, LDP leaders regularly appointed to the Supreme Court a career judge who had

\footnotetext{
${ }^{2}$ Saibansho ho [Judiciary Act], Law No. 59 of April 16, 1947; Saibankan dangai ho [Judicial Impeachment Act]. Law No. 137 of November 20, 1947, § 3. Judges can also lose their job if declared "mentally or physically incompetent" by a court (Constitution, Art. 78).

${ }^{3}$ For some empirical evidence that American federal judges may not act quite as independently as we have often thought, see Cohen (1992, 1991); Spiller \& Gely (1992); Toma (1991), De Figueiredo and Tiller (1996).

${ }^{4}$ To be sure, this does not make the institutional structure irrelevant. If judges know that the Diet can impeach them, that the Cabinet may refuse to rehire them, or that voters can expel them, they may ignore majority preferences less. If so, then in equilibrium, politicians and voters would not often exercise the institutional control anyway. Judges would not ignore majority preferences, and voters and politicians would not punish them.
}

${ }^{5}$ ZSKS (1990). On the frequency of impeachments in the United States, see Culver \& Cruikshanks (1982). 
headed the Secretariat. At all times, therefore, they had on the Court a loyal partisan who knew in detail how the administrative offices worked.

LDP leaders used this control over the Secretariat to reward judges in part according to whether they decided politically important cases the way the LDP politicians and voters wanted. Through the Secretariat, they institutionalized a system in which judges who decided controversial cases the right way by their lights (and who otherwise did good work) went to important positions in Tokyo. Others went to the branch offices. Indirectly to be sure, through this control over job assignments they influenced judges by promoting some and by not promoting others.

II. The United States

A. The Twentieth Century:

In contrast, American federal politicians implicitly follow a strict hands-off-the-courts rule. Unless a judge is insane, rankly incompetent, or crooked, they let him sit in court and draw the standard salary. Whether he implements the majority party's ideology or anything else, they largely let him be.

American federal politicians do try to shape judicial ideology at the stage of a judge's initial appointment, but not later, and often not even then Over the decades, some politicians have weighted ideology heavily, others more lightly. Few, however, have ignored it altogether, and few have picked more than a trivial number of judges from the rival party (Freund, 1988).

Nonetheless, the implicit hands-off-the-courts rule is strong enough that sometimes observers criticize even attempts to influence the judiciary at the appointment stage. When Ronald Reagan nominated Robert Bork, some Democrats claimed he violated an implicit agreement to appoint only centrist jurists. When Bill Clinton named Lani Guinier to a position in the Attorney General's office, many Republicans argued the same. And when the Senate, which must approve all appointments, hesitates because of ideology, the President's supporters cry foul. The Democrats' successful campaign to block Bork gave rise to the derogatory term "borking", even though it was merely a publicity campaign to influence senators' approval votes.

The implicit hands-off-the-courts rule is deeply held, as Franklin Roosevelt discovered. When the Supreme Court rejected his New Deal, he proposed to enlarge the Court. Nothing in the Constitution required that it have nine justices. Indeed, politicians had manipulated its size to political ends before, ${ }^{6}$ and one of the Court's hostile judges-James McReynolds-- had, when US Attorney General in 1913 as part of a Democratic Administration that followed a long string of Republican presidents, authored a report favoring a court-packing scheme much like Roosevelt's (Manchester, 1973: 183). And increasing the size of the lower courts was, everyone seemed to think--and still thinks-- perfectly fair game (see De Figueiredo \& Tiller, 1996). By enlarging the Court to fifteen and appointing committed New Dealers to it, Roosevelt planned to build the Court majority he needed to implement the programs for which he won his electoral landslide (Currie, 1990: 235-36; Leuchtenburg, 1966).

Even Roosevelt's friends balked. Not only were judicial careers off-limits to American politicians, apparently the number of justices was off-limits too. Roosevelt may have won by a landslide in 1936, but in politics, as in much of life, turnabout is fair play. What the

\footnotetext{
${ }^{6}$ See the discussion of the 1801 Judiciary Act, below, and the instances cited in Choper (1974: 850-52); Mason (1937: 667-68).
} 
Congressional Democrats could do to the Republicans, someone else-perhaps the Republicans, perhaps President Roosevelt-- could do to them. The Congressional Democrats knew that they would eventually lose office, either to a revived Republican party (as actually happened) or to a different faction of the Democratic Party. ${ }^{7}$ If they set a precedent for manipulating Court size now, it could come back to haunt them. That, many of them did not want. Rather than renege on the implicit rule now, they opted to risk Roosevelt's entire program.

\section{B. The Early Nineteenth Century:}

By the standards of the early republic, Roosevelt's scheme was meek. Politicians a century earlier had not followed any hands-off-the-courts rule. Before the Revolution, the Crown had sometimes controlled judicial careers (Surrency, 1967). After the Revolution, voters in many states did the same. Some states made judges elected officials and kept them on a short lease with one-year terms. Others gave control to the politicians, letting their judges hold office only at the pleasure of the legislature (Ellis, 1971).

Not only were state court judges subject to loss of their jobs, federal courts were fair game too. Consider the shift from Federalist to Republican rule. ${ }^{8}$ In 1800 , Thomas Jefferson beat John Adams in a bitter election, and Adams was not amused. With but two weeks left in his term, he engineered the 1801 Judiciary Act (2 Stat. 89). Through it, he expanded the judiciary and packed it with party loyalists (Turner, 1961). Along with stacking the courts, he also cut the size of the Supreme Court. It had been six. He now cut it to five, effective on the next retirement. Thereby, he prevented Jefferson from appointing anyone to the court until two justices quit.

Upon taking office, Jefferson retaliated in kind. First, he fired Adams's nonjudicial appointees. Then he fired all the new judges. Given Article III of the U.S. Constitution, he could not do so directly, of course. If Adams's Congress had passed the 1801 Judiciary Act, however, Jefferson's Congress could repeal it. Repeal it his Congress did (2 Stat. 132, 1802). In the process, it threw the judges appointed under the 1801 Act out of their jobs. By the Constitution, they held their office during "good Behavior." Yet their office itself was a creature of Congress, and what Congress could create, Congress could abolish. It abolished their offices, and the judges were judges without postings - whether on good behavior or bad. Lest John Marshall's Federalist Supreme Court rule the ploy unconstitutional, Congress recessed the Court for fourteen months. ${ }^{9}$

By the time the Supreme Court finally faced the issue, even the Federalist justices had lost their nerve. They declined to hold the 1802 Act unconstitutional (Stuart v. Laird, 5 U.S. (I

\footnotetext{
${ }^{7}$ In 1937 Roosevelt's Democrats controlled over 75 percent of each house of Congress. In 1936 the Republicans had lost 5 million presidential votes since their heavy defeat in 1932, the first Depression election and Roosevelt had won the presidential electoral college 523 to 8, joking, "I knew I should have gone to Maine and Vermont..." (Manchester, 1973: 174). Yet by 1946 the Republicans had regained Congress, and in 1952, the Presidency.

${ }^{8}$ The Republican Party of Jefferson eventually changed its name and is the Democratic Party of the year 2000. The present-day Republican Party was only founded in the 1850 's.

${ }^{9}$ Even at the time, not all observers thought that the judges should lose their salary. See Story (1833: v. 3, 494) (on the 1802 Act: "if its constitutionality can be successfully vindicated, [it] prostrates in the dust the independence of all inferior judges"); Haskins \& Johnson (1981: v. 2, 171-72). More recently, at least some Supreme Court justices have argued that abolishing the courts would simply create salaried judges without courts. See, e.g., Glidden v. Zdanok, 370 U.S. 530, 544-47 (1962) (Harlan, J.).
} 
Cranch) 299 (1803)). Discretion may have saved them their jobs, for many Republicans were ready to go further. Some wanted to amend the Constitution and appoint judges to serve at the pleasure of Congress. Others wanted to abolish the courts altogether and rely on the state courts (Ellis, 1971: 21).

Moderation prevailed. The Republicans never amended the Constitution to control the judges, and no one even abolished judges' jobs again. Indeed, when Congress abolished the Commerce Court at the turn of the century, it simply kept the judges on the payroll (Donegan $v$. Dyson, 269 U.S. 49 (1925)). By Roosevelt's time, this moderation had become the modern hands-off-the-courts rule. Even Supreme Court size was now sacred.

\section{Judicial Might-Have-Beens:}

As we have seen, in America the constitutional text is not always a good guide to constitutional practice. The Constitution allows Congress to abolish judicial offices, limit jurisdiction, change Supreme Court size, and reject presidential appointments, but the extent to which these practices have been used has varied widely over time. Japanese and American politicians treat judges differently, but not because of any differences in the constitutional text. If they chose, Japanese politicians could insulate judges from political control. At least by the text of the Constitution, American politicians could intervene LDP-style in the courts.

Start with the Japanese Constitution. It does not forbid the Japanese government from passing implementation laws setting up a system very like the American one. The chief constraint on the lower courts is Article 80, which says, "The judges of the inferior courts shall be appointed by the Cabinet from a list of persons nominated by the Supreme Court. All such judges shall hold office for a term of ten(10) years with privilege of reappointment, provided that they shall be retired upon the attainment of the age as fixed by law." Thus, the Supreme Court and Cabinet must agree on appointments, rather than the President and Senate as in the United States. But the Diet could pass an implementation law setting a retirement age of 100 and establishing separate posts for trial courts and appellate courts, and it could specify that judges are not to be transferred from their initial posts without their consent and without going through the appointment process again. Combined with the current custom of almost-automatic reappointment, the result would be much like the current U.S. federal system. Thus, the constitutional text does not mandate the current system in Japan; it could be changed by the politicians if they wanted.

Look now to the U.S. Constitution. Once a judge takes office, the President cannot freely fire him or dock his pay (U.S. Const., Art. III, § 1). Suppose John Doe becomes President and appoints eminent University of Chicago Professor I. Jones to the local Seventh Circuit Court of Appeals in downtown Chicago. Neither Doe nor any of his successors could fire Jones without evidence of serious fault (U.S. Const. Art. III, § 1; Shartel, 1930; Block, 1970). Neither could anyone reduce his pay. That is all the American Constitution says on point, and the Japanese Constitution says much the same thing. Legislatures in both countries could impeach judges whose decisions they disliked, but in neither country do they impeach except for such things as criminal offenses. 
Where the two systems diverge is not in their constitutions, but in the laws that the legislatures pass to implement the day-to-day aspects of a judicial system -- what judges do, and where they do it. In principle, these laws can be changed as easily and often as the tax code. We have seen that politicians in Japan could change the judicial administration law to imitate the U.S. system if they wished. Similarly, in America our hypothetical President Doe need not be very creative to penalize Judge Jones. Even under the existing statute, he can transfer him. For example, suppose the President has the Chief Justice on his side. If he can make a plausible showing of need, he can order Jones to show up "temporarily" for work in Omaha (28 U.S.C. § 291).

Or suppose President Doe, like Roosevelt and the LDP, has a majority of his party in the legislative branch. He decides the Seventh Circuit is a hotbed of unreconstructed radicals. To punish the judges, he could merge the Seventh Circuit into the adjoining Eighth (28 U.S.C. § 48). He could then force the Chicagoans to appear for work in either St. Louis, Kansas City, Omaha, or St. Paul. Or maybe all four, in rotation. The Supreme Court itself once held that Congress could order the justices to ride circuit (Stuart v. Laird, 5 U.S. (I Cranch) 299 (1803)). By comparison, sending Chicago judges to Omaha seems mild.

More comprehensively, if President Doe's allies controlled Congress they could import the entire Japanese system on a turnkey basis. They would first abolish the statutory circuit designations (28 U.S.C. $§ 48$; Posner, 1985: 25). All judges would then serve on one national circuit. Either directly or through the Chief Justice, Doe could now transfer judges at will. Like the LDP leaders, he would reward the faithful with glamorous posts. He would dispatch the renegades to the outback.

Indeed, Doe could do more. The President now appoints judges as either district or circuit judges (28 U.S.C. $\S \S 44,133)$. With a modest statutory change, he could appoint all judges as "federal judges." Depending on their performance, he could move them on or off appellate panels. Similarly, all district judges now earn the same pay, and so do the circuit judges. With a little change, he could establish a salary range, staring everyone with a low salary and then rewarding the faithful with bigger and more frequent raises.

The U.S. Constitution prevents none of this. Before 1891, the President appointed only two tiers of federal judges -- district judges and Supreme Court justices (Act of Mar. 3, 1891, ch. 517, 28 Stat. 826; Posner, 1985: 23-24). As recently as 1875, district judges received a salary from a pay range (Posner, 1985: 43). And when the Congress abolished the short-lived Commerce Court (Act of Oct. 22, 1913, 38 Stat. 208, 219), existing Commerce Court judges became judges without a court. Like Japanese judges, they sat wherever the Supreme Court Chief Justice told them to sit (Donegan v. Dyson, 269 U.S. 49 (1925)).

Although modern Japanese judges enjoy less political independence than federal judges, the difference has nothing to do with the constitutional text. The Japanese Constitution does not require the ruling party to intervene in the courts; the American Constitution does not prevent Congress and the President from intervening in the courts. Before considering further why modern Japanese and American politicians do adopt different approaches (in Section IV), consider first the approach that Japanese politicians took before the Second World War (in Section III).

III. Imperial Japan

A. Introduction: 
The 1889 Japanese Constitution ${ }^{10}$ seemed to give judges less independence than the modern Constitution. After all, the imperial judges were under the Ministry of Justice rather than a formally independent Supreme Court. Nonetheless, actual practice differed little. Before the Second World War as after, political leaders could use the judicial career structure to influence the way judges decided cases.

B. Judicial Structure:

The 1889 Constitution (Art. 58(b); see Arts. 59-61) set the basic institutional contours of judicial independence: "no judge shall be dismissed from work except through a criminal conviction or disciplinary disposition." The 1890 Judicial Organization Act (1890 Act $)^{11}$ specified the detail for this constitutional mandate. Although it placed courts squarely within the Ministry of Justice (1890 Act, $\S 135$ ), it insulated judges from control in several ways. ${ }^{12}$

First, the 1890 Act prohibited the Minister of Justice from transferring a judge against his will (1890 Act, § 73). Second, it let him order a judge to retire only if the judge no longer had the physical or mental capacity to perform his work and he obtained the approval of the en banc High Court or Supreme Court (1890 Act, § 74). Third, it let him discipline a judge only if the judge had misbehaved egregiously, and only through proceedings before panels of either the High Court or the Supreme Court. ${ }^{13}$ Last, because the act did not specify a mandatory retirement age, it effectively gave judges life tenure. Thus, the imperial judge had all the protections of the modern judge, and more besides.

This institutional framework made it hard for government leaders to manipulate the judiciary. Notwithstanding that difficulty, the oligarchs of late $19^{\text {th }}$ century Japan soon decided to do an end run around this framework, as we will shortly describe. Thirty-some years later, the professional politicians who followed them to power would do the same.

\section{Oligarchic Manipulation:}

At the turn of the century, a clique of unelected oligarchs held power in Japan. Formally, they held power by virtue of their access to the Emperor. Substantively, they held it by virtue of their control over the military. Already by the mid-1890s, these men had intervened in the judiciary.

These oligarchs intervened primarily for technical reasons, not political ones. They had

${ }^{10}$ Dai-Nippon teikoku kempo [The Constitution of the Great Japanese empire], promulgated Feb. 1, 1889.

${ }^{11}$ Saibansho kosei ho [Judicial Organization Act], Law No. 6 of Feb. 10, 1890. Further details on the status of judges were determined by the Hanji kenji ken nado hokyurei [Order Regarding the Compensation of Judges and Prosecutors, Etc.], Chokurei No. 17 of Feb. 14, 1894.

${ }^{12}$ Why the oligarchs did this is not clear, though it probably had to do with renegotiating the consular jurisdiction imposed by Western governments under the treaties in effect at the time.

${ }^{13}$ The judge would then face penalties ranging from pay cuts to impeachment. Hanji chukai ho [Judicial Disciplinary Act], Law No. 68 of August 20, 1890, §§ 2-9. 
created the judicial system itself in $1872 .{ }^{14}$ During the first two decades, they had hired as judges men with very little legal education. They had had little choice, for legally trained men were not available. By the 1890s, the new university system gave them a large cadre of men with sophisticated legal training. Accordingly, if the untrained judges could be removed, they could be replaced by newcomers far better educated. Therefore, during the nineteen months from July 1893 to March 1894 and August 1898 to May 1899, they told 158 judges to retire. ${ }^{15}$

The institutional framework did not make this straightforward. If the Minister of Justice ordered a judge to retire, or even to move to an obscure provincial court, the judge could properly refuse. If the Minister wanted to force the judge to retire, he had to submit the matter to the High Court or Supreme Court with accusations of incapacity or misconduct. He had no assurance, however, that the courts would decide matters the way he wanted, and in any case the publicity would be undesirable and stigma would be attached to ex-judges who were, after all, first appointed by the patronage of the ruling clique.

So to induce judges not to contest his contestable order, the Minister of Justice bribed them. He did this by promoting them to more prestigious courts at higher pay in exchange for their agreeing to retire quickly and quietly thereafter. This not only gave them the face-saving chance to resign from a higher court, and after a recent promotion had indicated the government's regard for their talent, it also boosted their pension. Under the rules then in effect, a judge's pension depended on his total years of service and his final pay. ${ }^{16}$ If he earned his final high salary for a day, he earned a highly paid judge's pension for the rest of his life.

The Minister of Justice bribed judges with pensions on a wide scale. During the last months of 1898 and early months of 1899, the Ministry of Justice even appointed 15 judges to the 29-member Supreme Court. ${ }^{17}$ Court-packing? No. The new judges served terms of one day to three weeks each. The Minister agreed to name them to the Court; they agreed to quit; and everybody kept their bargain. The judiciary was rejuvenated, and if there remained some less competent old judges who had refused the bribes, they were few enough not to reduce the effectiveness of the system at delivering legal decisions to the public.

\section{Political Manipulation:}

Over the next several decades, control of the Cabinet gradually shifted from the aging Meiji oligarchs to a new breed of professional politicians in the Diet. In 1889, shortly after the promulgation of the Constitution, Prime Minister Kuroda made it clear that constitutional government did not mean government at the behest of the voters. In a famous speech he laid out his theory of "transcendental government," in which not just the judiciary but also the executive

14 See Shiho shokumu teisei [Rules Regarding Judicial Functions], Dajokan unnumbered Tatsu of Aug. 3, 1872. The Supreme Court (Daishin'in) was created by the Daishin'in sho saibansho shokusei shotei [Rules and Duties of the Supreme Court and Other Courts], Dajokan Fukoku No. 91 of May 24, 1875.

${ }^{15}$ Ramseyer \& Rosenbluth (1995: ch. 6). The capacity of the courts at the time was about 1200 judges. See Chokurei No. 17 of Feb. 14, 1894 (1,220 judges); Chokurei No. 122 of June 20, 1898 (1,195 judges).

${ }^{16}$ See Kanshi onkyu ho [Government Employee Pension Act], Law No. 43 of June 21, 1890, $\$ 5$.

${ }^{17}$ Kusunoki (1989: 282-93). For the size of the Supreme Court, see Hanji kenji ken nado hokyurei, $\underline{\text { supra }}$ note $63, \S 2$. 
branch would be independent, free from the grubby hands of the politicians: "The government must always take a fixed course. It must stand above and outside the political parties and cleave to the path of supreme fairness and supreme justice. (Sashihara, Meiji Seishi, p. 1931, as reported in Mitani, 1988, p. 57). If judicial independence is a good thing, why not executive independence? With the military and the other oligarchs on his side, nobody argued with Kuroda in 1889. By the 1920's, however, power had shifted. The transition was gradual, but 1924 was a turning point. In that year, after two years of cabinets that contained not a single member of the House of Representatives, the politicians rebelled. The leaders of the major parties announced their dissatisfaction, formed a coalition, and won the next general election. The Cabinet of peers resigned and was replaced by a politician-dominated cabinet. From that time until 1932, Japan clearly had an executive branch responsive to the electorate. The oligarchs were gone, and the politicians were in control. Ominously, an independent military waited in the wings, no longer under the personal control of the people running the government. In the judicial sphere, the politicians inherited from the oligarchs an institutional legacy that complicated their ability to constrain judges.

At an aggregate level, the data on senior appointments in the Ministry of Justice in panel A of Table 7-1 show a curious pattern of political involvement from 1925, the year of the first Cabinet after grand coalition of 1924 fell apart, to 1931, the year before the military commandeered the government. Panel A shows the number of months from a Cabinet change to personnel change, if any personnel change did occur within a year after the Cabinet change. The Parliamentary Vice Minister was of course immediately changed every time - that post is meant to be occupied by a politician. The equally high-ranked Administrative Vice Minister of Justice was replaced only by Prime Ministers Giichi Tanaka and Tsuyoshi Inukai. No prime minister ever replaced either the Civil Bureau Chief or the Chief Prosecutor. Panel B shows statistics for somewhat lower-ranked officials, comparing how many posts were reassigned in the first two months of the new Cabinet with how many were reassigned in the subsequent ten months. Except for Inukai's replacement of 12 chief district court prosecutors (of which more later), no new Cabinet ever replaced more than three officials in the ranks covered by Panel B within two months. Adding ten extra months increases the turnover considerably, but even then less than half the officials are replaced - and remember that parties stayed in power only about two year at a time during this period. Compare this with the United States, where despite the inevitable disruption in government business it creates, a new administration of a different party replaces en masse not just the higher-ranking officials, but the U.S. Attorneys, the equivalent of the Chief Prosecutors of the District Courts.

To the U.S. observer, the turnover in judges in Panel B of Figure 7. 1 looks higher. Although judges were not replaced immediately after the new Cabinet gained control, within a year an average of 16.25 of the 51 chief judges of district courts were replaced. Is this a large number? Not really. If a typical term in a particular posting was 3 years, as it was post-war, the number would be 17 , even without any political intervention

Table 7.2 takes a different approach. Focussing just on judges, it shows the number of (a) appointments to the Supreme Court and (b) forced retirements of judges generally. It shows the number of each of these in the four months of a Cabinet of a new party and the four months immediately preceding the Cabinet change. Notice first that until 1931, none of the three prime ministers who replaced a prime minister of a different party either appointed more supporters to the top of the judiciary (the Supreme Court) or fired more at the bottom (through forced retirements) than their predecessors had done in the preceding four months. The preceding 
Cabinets appointments could all have been fired, and those judges they forced to retire could have been reappointed, but this seems not to have happened. On reconfiguring his Cabinet in 1925, Kato seems not to have fired any more judges than he had in the months before. Tanaka and Hamaguchi fired a few more, but the difference barely shows. These tables do not show intervention in the judiciary taking the form of replacing the previous adminstration's judges with one's own. Rather, the personnel of the judiciary stayed largely the same. By U.S. standards, firing about one judge per month seems extreme, but at that rate, it would take a long time to turn over the entire judiciary. That the firings were not concentrated in the months after a new party took power suggests that the firings were relatively nonpartisan, the exercise of political control but not partisan control. We may speculate that the judges were fired for incompetence or misbehavior, or for political reasons on which all of the parties strong enough to form Cabinets agreed: that socialists are bad and so are holdovers from the Meiji oligarchy and supporters of the army who show signs of favoring transcendental or military rule.

While showing that partisan politics was not a major force in the judiciary, however, Tables 7.1 and 7.2 understate the extent that politicians manipulated the courts. Back in 1913, the Seiyukai had controlled both the Cabinet and the Diet. That April it set out to reshape the personnel of the courts. It first amended the Judicial Organization Act to ease its job. ${ }^{18}$ Under the revised act, the Minister of Justice could transfer judges against their will by a simple majority vote in either the High Court or the Supreme Court. Through a similar vote, he could place as many as 232 judges and prosecutors on inactive status. From April to June, the Minister retired 98 judges and prosecutors, placed 131 on inactive status, and transferred 443 (Nomura, 1966: v. 3, 382).

When the Seiyukai regained the Diet and Cabinet several years later, it instituted mandatory judicial retirement (Law No. 6 of May 17, 1921). By doing so, it automatically purged many of the men appointed by the oligarchs and could install its own. During the dozen years after 1913 , it controlled the Cabinet only about half of the time. Although the remaining years might have given the rival Kenseikai party time to appoint its own sympathizers to the Ministry, it did not. Instead, it wasted almost half its term in office with a Minister of Justice, Yukio Ozaki, who had little interest in personnel issues (Yamaoka, 1925; Shiho, 1925).

The Seiyukai thus did intervene in the Ministry of Justice in the years before Tables 7-1 and 7-2. The rival Kenseikai party was not altogether passive either. Consider the career of Mannosuke Yamaoka. On finishing college in 1899, Yamaoka worked as a prosecutor's apprentice and then as a Tokyo judge. After a stint in Germany, he returned to Japan in 1910 as a prosecutor. By 1914, he had endeared himself to a Seiyukai-affiliated senior bureaucrat. With that patronage, he moved into a series of important posts, and by 1925 headed the Criminal Bureau. Then, under a Kenseikai Cabinet, the Minister of Justice summarily placed him on inactive status (Hosojima, 1964: 45-95; Shiho, 1925). Legal commentators complained that politicians were politicizing the judiciary, but Yamaoka was graceful in his response:

I do think I've been impartial, ... but if you look at the Ministry of Justice from the Kenseikai's perspective, you'll see it's just about completely stacked with Seiyukai people. It's true that Mr.

\footnotetext{
${ }^{18}$ Law No. 6 of Apr. 5, 1913; Law No. 7 of Apr. 5, 1913. Law No. 6 in fact provided that the transfer provision applied "when necessary for trial business." Because the Judicial Organization Act already allowed the minister of justice to transfer judges when it was necessary to fill a vacancy (1890 Act, $\S 73$ proviso), ordinary canons of statutory interpretation suggest this was a looser requirement.
} 
Ozaki was Minister of Justice for a while under the [1914] Okuma Cabinet, but he stayed almost totally aloof from these things. As a result, there's hardly any trace of the Kenseikai there. (Shiho, 1925)

Whatever modest independence the judiciary had in the 1920's it lost completely when Seiyukai party leader Inukai became prime minister in 1931-he of the 12 prosecutors replaced within two months in Figure 7.1B. Because the military usurped the government in 1932, he was the last prime minister to take office as a party politician. He dominated the courts straightforwardly. ${ }^{19}$ Even before he took office, some observers predicted he would make massive changes (3352 Horitsu shimbun 17 (1931)). He did indeed. Within four months of taking office on December 13, 1931, he appointed 13 justices to the 29-member Supreme Court and fired 29 lower-court judges (Table 7-2). A day later (on April 14, 1932), he announced yet another massive series of personnel changes. The legal press called it "The Great Judicial Office Shuffle." In one day, he transferred 213 judges and prosecutors (3396 Horitsu shimbun 19 (1932)). Perhaps he was relying on his overwhelming electoral victory over the opposition Minseito Party. Neither electoral strength nor judicial intervention proved as decisive, however, as Inukai's assassination by a group of naval cadets a month later on May 15, after which he was replaced as Prime Minister by Admiral Saito.

All told, the independent judiciary has a spotty record in imperial Japan. Under the oligarchs, it lacked independence--though with good effect on its professional quality. Under the politicians, some prime ministers were strong enough and interested enough to try to change the personnel of the judicial branch and others were not, and by the end of party rule, judges clearly lacked independence.

${ }^{19}$ The claim in Mitani (1980: 18-19) that the judiciary remained independent from the political parties misses some of what happened in the 1920s and almost all of what happened in 1931. 
Page 14

Table 7-1: Major Personnel Changes Within Ministry of Justice

\begin{tabular}{lllll}
\hline \hline Prime Minister: & Kato & Tanaka & Hamaguchi & Inukai \\
Cabinet formation: & $8 / 2 / 25$ & $4 / 20 / 27$ & $7 / 2 / 29$ & $12 / 13 / 31$ \\
Party: & Kenseikai & Seiyukai & Minseito & Seiyukai
\end{tabular}

A. Major posts: *

(months till a replacement)

Adm. vice minister

Par. vice minister

Chief, Criminal Bureau

Chief, Civil Bureau

1 month 1 month 1

1 month

Chief prosecutor, S.Ct.

Ass. prosecutor, S.Ct.

Chief justice, s.ct.

- $\quad-$

$-$

1 month -

B. Subsidiary posts: $†$

(reassignments within 2

months and the next 12

months)

Ch. prosecutor, High Ct.

0,0

0,4

3,1

2,0

( 7 posts)

Ch. prosecutor, D.Ct.

1,16

3,17

1,9

12,12

(51 posts)

Section chief, S.Ct.

0,0

0,1

0,0

0,1

(8 posts)

Ch. judge, High Ct.

1,0

0,1

0,0

1,0

( 7 posts)

3,19

0,14

3,12

2,14 
Notes: The Wakatsuki Cabinets are omitted because they followed Cabinets of the same party (the Kenseikai in 1926 and the Minseito in 1931).

* Months from Cabinet change to personnel change, if within one year; blank if there was no personnel change.

t Number of reassignments within two months, followed by number of additional reassignments within shorter of (i) subsequent ten months and (ii) period of time until change in party controlling cabinet.

Sources: Calculated on the basis of data found in Ikuhiko Hata, Senzenki Nihon kanryosei no seido, soshiki, jinji [The system, organization, and personnel of the pre-war Japanese bureaucracy] 359-65 (1981); Shiho sho, ed., Shiho enkskushi [A documentary history of the judiciary] 557-836 (1939, republished 1960). 


\section{Table 7-2: Judicial Forced Retirements During the Four Months Before and After Cabinet Changes}

\begin{tabular}{llll}
\hline \hline & Before & After \\
\hline A. No. of judges assigned to S. Ct.: & 5 & 3 \\
Kato (August 2, 1925, Kenseikai) & 1 & 2 \\
Tanaka (Apri1 20, 1927 Seiyukai) & 0 & 2 \\
Hamaguchi (July 2, 1929, Minseito) & 3 & 13 \\
Inukai (December 13, 1931, Seiyukai) & & \\
No. of judges forceably retired: & 16 & 15 \\
Kato (August 2, 1925, Kenseikai) & 13 & 10 \\
Tanaka (April 20, 1927, Seiyukai) & 9 & \\
Hamaguchi (July 2, 1929, Minseito) & 7 & \\
Inukai (December 13, 1931, Seiyukai) & &
\end{tabular}

Note: "Forced retirement" refers to judges officially ordered to retire-those for whom the notice "taishoku wo meizu" appeared in the official government gazette, the Kanpo.

The Wakatsuki Cabinets are omitted because they followed Cabinets of the same party.

Source: Compiled from the daily government gazette,
Kanpo [Government gazette] (various issues).

IV. A Theory of Judicial Independence

A. Introduction:

It is a tale of three courts: a relatively independent American federal judiciary, a relatively nonindependent modern Japanese judiciary, and an even less independent imperial Japanese judiciary. These differences do not derive from constitutional texts. Neither do they obviously derive from any stronger American taste for independent courts. After all, many Japanese observers react to judicial career manipulation with the same consternation that many Americans would show, and many Americans wish their judges could be forced to show more restraint.

Nor does modern theory explain the differences. To date, most scholars try to explain why rational politicians find it advantageous to use independent courts, rather than why some 
politicians find it advantageous while others do not. In perhaps the most innovative article on point, William Landes and Richard Posner (1975) advanced independent courts as a way for politicians to make long-term bargains with their constituents. Without independent courts, they argued, politicians would have an incentive to cheat on any deals their predecessors made-or, indeed, on any they made themselves. Constituents then reward politicians less for passing advantageous statutes, knowing that the statutes might be nullified by the courts at the politicians' direction.

Indeed, the problem would exist even in a one-party. Politician $\mathrm{X}$ might wish to accept contributions in exchange for passing law Y. If he can instruct the bureaucrats to disregard law $\mathrm{Y}$ and act as if it had never been passed, however, no forward-looking contributer would pay him for its passage. The government could not even obtain supplies by procurement contracts without paying a hefty risk premium; if the court were always on the government's side, the supplier would lose any contract dispute.

Independent judges, Landes and Posner suggested, mitigate this problem. Precisely because of their independence, they are willing to enforce legislative deals. By stopping successor parties from reneging on their predecessors' deals, and by preventing even the original parties to the deal from reneging, the judges would help all legislators extract the money or power for which they sold their deals to the voting public. Douglass North and Barry Weingast (1989) seem to find evidence for the theory in seventeenth-century England. Placed in a broader theoretical framework, the theory fits within what Oliver Williamson (1993; Moe, 1991) and others have since described as purposefully inefficient bureaucracies. "Incumbent politicians who create and design bureaus are aware that the opposition can be expected to win and take control in the future," explains Williamson. "A farsighted majority party will therefore design some degree of (apparent) inefficiency into the agency at the outset -- the effect of which will be to frustrate the efforts of successor administrations to reshape the purpose served by the agency."

Mathew McCubbins and Thomas Schwartz (1984) advance a hypothesis with a different twist - one we introduced in Chapter 5 in connection with tax disputes. They argue that independent judges help politicians monitor the people they appoint to bureaucratic posts. Monitoring bureaucrats routinely would entail resources politicians do not wish to use. Politicians instead keep bureaucrats in line by giving constituents a right to sue them in independent courts. In this theory, courts are kept independent of politicians because politicians would have to use bureaucrats to monitor non-independent courts, and this would make it difficult for the courts to monitor the bureaucrats.

Absent other considerations, both the Landes-Posner or the McCubbins-Schwartz theories imply that competitive electoral markets should lead to one equilibrium outcome: independent courts. Perhaps politicians who keep courts independent will more successfully raise money (Landes-Posner), or perhaps they will more successfully monitor their bureaucrats (McCubbins -Schwartz). In either case, politicians who keep courts independent should compete more successfully in electoral markets than those who do not. In either case, the forwardlooking politician will establish independent courts as the first item on his agenda. In either case, independent courts would arise over time even if politicians were less aware of their interests, as the evolutionary pressure of electoral competition drove politicians who could not keep their deals into extinction.

But of course this is not true. Not all regimes have independent judges. This calls attention to differences both among different types of cases, and among the electoral framework 
within which politicians compete. We discussed the former in Chapters 4 through 6 . We turn now to the possibility that the differences in judicial monitoring might result from different electoral exigencies. In the U.S.-Japanese comparison, those exigencies are twofold:

(a) the long-term electoral dominance of the LDP in postwar Japan compared to the erratic electoral performance of American political parties; and

(b) the long-term likelihood of continued democratic elections in the United States, compared to the short-term time horizons in imperial Japan.

B. A General Theory of Comparative Independence:

Although modern Japanese elections are highly competitive affairs, for nearly forty years the LDP consistently won them. ${ }^{20}$ Partly by shifting its policies to follow the shifting median voter and partly by using its control over government to give constituents generous private goods, it dominated the political marketplace (see generally Ramseyer \& Rosenbluth, 1997: chs. 2-5). By contrast, American parties win erratically. As a result, LDP leaders could reasonably expect that they would continue to control the government indefinitely. ${ }^{21}$ No American leader of either party could expect such a thing.

If politicians face significant odds of being in the minority party, they may rationally try to reduce the variance to their political returns. In part, they can do this by insulating the judicial system from political control. Suppose, however, that by virtue of institutional design or some other means, the incumbent party has little control over judges and cannot rely on them to help win elections. That party will be less likely to win the next election, but will also have a better chance to return to power later if it loses it. American politicians seem to have chosen this option.

LDP leaders had less reason to insulate their judges from election pressures. Because they could realistically expect to stay in power indefinitely, they placed little value on being able to return to power more easily if they lost it. Consequently, they could rationally elect to monitor judges instead, and thereby obtain greater control over policy. Although they increased the cost of losing an election, they accepted this, since they were less likely to lose.

At stake is an intertemporal calculus. American political leaders have increased their control over the future judiciary by reducing their control over the present one. They freely make political appointments, routinely naming party loyalists. By insulating these judges once appointed from political control, they increase the impact that these same appointments will have after they lose office. By politicizing appointments but depoliticizing control, they augment their influence during periods when they are out of power. All this, of course, comes at the cost of decreasing their influence over policy while in power. Because they must run the country with

\footnotetext{
${ }^{20}$ Japanese incumbents face a higher risk of losing office than incumbents in either Britain, West Germany (as it was), or the United States. See Calder (1988: 68).

${ }^{21}$ This conclusion is not affected by the LDP's loss in the summer of 1993. The point is not that the LDP had odds of winning of 100 percent every year. Rather, the point is that its odds were extremely high. Very few observers predicted the 1993 LDP loss, on the one hand; and on the other, it had some small probability of losing previous elections too.
} 
numerous independent judges appointed by their predecessors, they necessarily have less impact over policy while in office.

LDP politicians adopted the opposite tactic: they increased their control over judges in the present by decreasing the extent to which that control lingers into the future. ${ }^{22}$ By giving the party in power control over judges, they increased the electoral stakes. As long as they stayed in power, they kept tight control over policy. Once they lost an election, they sacrificed more power than a losing American party would sacrifice. Because LDP leaders rationally expected not to lose, they rationally took the risk.

The American equilibrium rests on nothing more than mutual cooperation. American politicians do not adopt LDP tactics. Yet they avoid them only by implicitly agreeing to use cooperative strategies in what they all recognize as a game that closely resembles an indefinitely repeated Prisoner's Dilemma (Kreps, et al., 1982). In such repeated games, however, implicit cooperation is fragile at best. Parties to indefinitely repeated Prisoner's Dilemmas do not necessarily cooperate. At least theoretically, they may do anything at all (Rasmusen, 1989: 92; Fudenberg \& Maskin, 1986; Buckley \& Rasmusen, 2000). They might agree to insulate their courts. Then again, they might not.

Yet one thing is certain, and that is that rational politicians will not cooperate if they cannot expect their rivals to do the same. The battle over the 1801 Judiciary Act illustrates the problem. Under the new Constitution, the transition in 1801 was the first. At the time, the Federalists had no idea what shape a Republican government would take. Given the French bloodbath and Jefferson's Francophilia, they could easily fear the worst. And even if Jefferson did not bring out the guillotine, the size of his victory, the extension of the franchise to poorer, non-Federalist voters, and the likely admission of new states in the non-Federalist West all portended a long period of Republican rule. Indeed, such a forecast would have been accurate; the Federalists disintegrated and the Republicans held the Presidency until they split into factions and a Whig won some forty years later. In that world, to exercise self-restraint out of a hope that the Republicans might reciprocate struck many Federalists as insane. Given that the Federalists showed no self-restraint, neither were the Republicans inclined to restrain themselves. Only as the decades passed and the parties alternated in power regularly did cooperation (and greater judicial independence) eventually evolve.

The contrast between the demise of the Federalists and the later demise of the Whigs in America is instructive. The Whig Party disintegrated in the 1850's because of the tension between its pro-slavery and anti-slavery factions, yet it did not try to interfere with judicial independence in its final years. Partly this was because the most controversial issue before the courts, slavery, was the one on which the leaders of the Whigs could not agree. Partly, also, was that although the Whig Party disintegrated, the Whig politicians themselves had a brighter future. They expected to continue in politics under some new party label, with a good chance of regaining power. And indeed what happened was that a coalition of ex-Whigs and dissatisfied Democrats formed an anti-slavery party, the Republican Party, which captured the Presidency within ten years.

It is noteworthy that the greatest breakdown in the American consensus on the judiciary occurred when the two-party system was at its weakest. This is shown not just by the events of

\footnotetext{
${ }^{22}$ Restated, American politicians politicize appointments but depoliticize control. Japanese politicians politicize control and therefore need not politicize appointments as strongly. A judge's personal preferences do not matter as much if he can be deterred from excercising them or transferred if he does.
} 
1801, but by those of 1937 . The Democrats' smashing presidential and congressional victory of 1936 was followed by Roosevelt's attempt to pack the Supreme Court. That he failed, at least in the court-packing plan itself, is less important than that he tried.

Although two parties alternated in power in imperial Japan, by 1931 they also intervened in the courts. Here, the explanation lies in the fear of a military takeover. Parties to a repeated Prisoner's Dilemma will often defect if they expect the game to end soon (Selten, 1978). The higher the odds that it will end, the higher the odds they will defect. By the late 1920s, few in Japan expected democracy to continue forever. The military had almost entirely removed itself from civilian control. Abroad, it was aggressively expanding onto the continent, conducting a foreign policy at odds with that of the elected government. Domestically, it was beginning to threaten coups d'etat. Democracy was on borrowed time, and anyone who followed Japanese politics knew it. For just that reason, rational politicians increasingly adopted endgame tactics.

If all this be true, then whether any coalition of rational voters will provide independent courts depends primarily on electoral probabilities. At root, it involves three possibilities.

1: Alternating-Party Regime.

Coalition $\mathrm{X}$ is in power but expects to alternate in power with Coalition $\mathrm{Y}$ indefinitely (the modern American parties). The two coalitions may rationally have an understanding that whoever is in power will keep judges independent, but nothing in game theory says that is the only possible understanding. Just as easily, it may be that the two coalitions engage in cutthroat competition with a politicized judiciary, to their mutual detriment but with no easy way out.

2: Dominant-Party Regime.

Coalition $\mathrm{X}$ is in power and expects to stay in power indefinitely (the postwar LDP). Coalition $\mathrm{X}$ may manipulate the courts. Coalition $\mathrm{X}$ earns the greatest return from a hand-off-the-courts strategy if it expects to be out of power periodically. If it does not expect to lose power, it has less incentive not to monitor and discipline its judges, both for reasons of pure politics and of efficient court administration.

\section{3: End-Period.}

Coalition $\mathrm{X}$ is in power but fears it may lose power soon and will never regain it later, regardless of whether the judiciary remains independent after its defeat (the prewar Japanese parties, or the American Federalists). Some other coalition Y-- the military in Japan, the Republicans in the United States-- is about to take its place indefinitely. $\mathrm{X}$ has no reason to hold back from manipulating the courts to make the best of its present situation and perhaps delay its terminal loss of power.

The idea behind the behavior we expect in all three regimes is that sometimes inefficient behavior is the only equilibrium outcome in a repeated game with short-sighted players but efficient behavior can be the outcome if players are far-sighted. The LDP maintains courts with some independence because it wishes to maintain a reputation for keeping its commitments and for courts which will decide impartially between private parties regardless of their political clout. Keeping commitments and deciding impartially are efficient outcomes, given the goals of inducing people to rely on those commitments and to engage in business dealings in reliance on the law for such things as contract enforcement. The LDP would acquire a short-term benefit 
from bringing the judiciary until tight control, but it would sacrifice other benefits in future years.

Let us denote the value of the short-term benefit from interfering with the judiciary, as viewed from the present by the decisionmaker, as S; and the long-term cost as L. For independence to be an equilibrium requires that

1. L is positive (nonindependence must have some cost).

2. L is large relative to $\mathrm{S}$

3. The decisionmaker has a long time horizon (long enough to make L large).

Consider the sort of crude interference in the courts represented by the forced retirements in prewar Japan. For the LDP, with its professional politicians and sound prospects for staying in power, the cost L to this would be very large. For the political parties in imperial Japan in 1931, with the threat of military takeover looming, L was not so large, and the more profitable course was to take the short-term benefit $\mathrm{S}$.

This depends completely on $\mathrm{L}$ being large relative to $\mathrm{S}$. One thing $\mathrm{L}$ depends on is the time horizon used by the decisionmaker, but that is not the only thing. Underlying the discussion of the previous paragraph was the assumption that L was positive - that there were indeed longterm benefits from the decisionmaker holding back from seizing the short-term benefit S. Remember: the LDP did not allow its judges complete independence. On certain kinds of issues - the constitutionality of the military, injunctions against the national government, and issues involving electioneering - we found that judges deviated from the LDP line at their peril, even if no such peril seemed to exist for criminal or tax cases or for injunctions against local governments. Our explanation for this is that $\mathrm{L}$ is small or negative for the first set of issues and large for the second set. The LDP would seem to derive no long-term benefit from being forced to adhere to the more impractical clauses of the constitution the American Occupation forces gave Japan some years before the LDP was formed, or from agreeing to let judges intervene in the executive branch by issuing injunctions against its decisions. Nor, from the point of view of the LDP, was there any point to establishing a reputation for fair play against electoral rivals. Those rivals were unlikely to ever be able to pay the LDP back in kind, especially if the LDP interfered with the rules of the game. Thus, when it came to those issues, there was no tradeoff between the short run and the long run.

Similar calculations are made by parties in an alternating-party regime, but the outcome is different. There, the ruling party does have to worry about upsetting an implicit deal to not coerce judges. The result of upsetting the deal would be an equilibrium in which both parties rigged elections to give themselves an extra margin and in which statutory and constitutional interpretation flipped back and forth depending on who was in power. Quite possibly, this longterm loss L would outweigh the short-term advantage $\mathrm{S}$, and the ruling party would adhere to the implicit deal.

Thus, the theory not only predicts the degree of judicial independence, but what kinds of intervention will take place. A longterm player, whether alternating in power as in (1) or secure in power as in (2), would like to be able make commitments and monitor bureaucrats, as noted by Landes and Posner and McCubbins and Schwartz. Where the two situations differ is in two respects. First, as mentioned above, a party that alternates in power has less motivation for making the bureaucracy and court administration effective. Part of the benefit from that, after all, will go to the next party in power, helping that party carry out its policies. Second, a party that 
alternates in power cannot make as effective use of promotion policies. If judges have posting of fixed terms, the party may not be in power by the time an offending judge is up for his next posting. Even if the party is in power at the right time, it only controls the postings while it is in power. When the other party comes to power, it can reverse any punishment or reward. Moreover, a party only temporarily in power will find it difficult to delegate the implementation of judicial promotions to an administrative secretariat. There is a fixed cost to creating a loyal secretariat, and time is required to test the loyalty of its individual members. The LDP could foresee enough years in power for it to be worthwhile to shape a dependable secretariat and rely on it to keep the judiciary in line. Any party that replaced the LDP would have to intervene more directly in the judiciary rather than delegating the task to experienced bureaucrats. Thus, we predict that lack of an independent judiciary in regime (2) would manifest itself more in direct intervention by politicians - say, by firing judges outright - than by promotion policies. The same is true of regime (3), since that regime, too, has little time in which to influence the judiciary before it loses power.

\section{Other Courts: European Courts, and State Courts in the United States}

What of other court systems besides the three we have been discussing? We can make predictions according to the theory, even though testing them would require additional institutional and empirical investigation.

For bureaucratic court systems similar to Japan's, the outcome of political influence via posting should be the same as in Japan if, as in Japan, the country's ruling party expects to stay in power indefinitely. Italy during the Christian Democrat years of the 1960's and 1970's is perhaps in this category. In a country with the same court system but ruling parties that alternate in power, the prediction is weaker. There, we would expect to see the cruder interventions of 1920's Japan, or less effective use of judicial promotions and transfers. Germany during the 1950's to 1980's, when Social Democrats and Christian Democrats alternated in power, might fit this category. In many countries the picture is further complicated by the frequency of coalition governments, which would to some extent differ as to what they wanted judges to do. Japan's LDP is in some respects like a coalition, in that its factions compete against each other for influence, but the LDP factions do not differ much in policy preference-certainly not in their support for the Self-Defence Force or for laws that would keep make electioneering difficult for minor parties, issues we have used in our regressions in this book.

Prediction becomes more difficult for systems that are neither like the Japanese system, with entry by examination, life tenure, and promotion by a secretariat, or the U.S. federal system, with entry by political appointment, life tenure, and little chance of promotion. Most of the state courts in the United States fit neither category. The United States has parallel court systems. In each state there are federal courts to adjudicate federal laws and to adjudicate disputes between citizens of different states, but there are also state courts, to adjudicate state laws. The U.S. President appoints federal judges, with the consent of the U.S. Senate, but he has no role in appointing state judges. Rather, each state decides its own method, and they have 
chosen a wide variety of them. Consider just state supreme court judges (lower-court judges are often chosen differently). The stage of initial selection includes partisan election, nonpartisan election (where the judges are not identified by party on the ballot), appointment by the governor (sometimes from a set of nominees by a committee of lawyers), and appointment by the legislature. Once in office, their terms vary from 6 year to life. In some states, to retain their jobs judges must face re-election or reappointment, and in some an appointed judge must win a retention election in which voters vote for or against him but without any other candidate on the ballot.

Why states have such a variety of features and terms of office is a fascinating question. Even the theoretical predictions of our repeated-game model for which states will choose which methods are somewhat unclear. For one thing, a distinction needs to be made between selection and retention. It is often said that elected state judges are not independent because they owe their position to the voters. Being elected by the voters directly, however, makes a judge no less independent than does appointment by the President. In both cases, the judge is not chosen randomly or by passing an examination: someone has done the selecting on the basis of both the judge's views and his abilities. Once selected, the judge does not lack independence merely because someone else chose him. Even if he made campaign promises, those are no binding.

Rather, what matters to judicial independence is what happens to someone currently a judge in the future. If the President could refuse to renew a judge at the end of a ten-year term, that would limit the judge's independence. Similarly, if the electorate can refuse to re-elect a judge at the end of a ten-year term, that limits the judge's independence. If, on the other hand, the judge is restricted by law to one term, that judge will be independent-he has nothing to lose by making controversial decisions.

What matters, then, is the length of a judge's term in a particular post, his promotion possibilities, and what determines whether he retains his post for a succeeding term. It is not that elected judges are less independent, but that re-elected judges must worry about their futures. An effective way to insulate judges from outside influence would be to pass term limits forbidding them to be reappointed or re-elected, but no state has done this.

We need to make somewhat finer distinctions in institutions once the different systems used in the U.S. state courts are to be considered. First, independent judges are not the same as an independent judiciary. Suppose judges are limited to a single nonrenewable two-year term, after which new judges are elected. Those judges will be independent, but if the voters want to use the judiciary to reverse a law, they can do so within two years by electing new judges chosen for their desires, independent of personal gain, to reverse the law. The judges are independent, but not the judiciary, and such a judiciary will not serve the purpose of commitment to government promises suggested by Landes and Posner.

Another difficulty for fitting the different states' methods into our theory is that once judges may be directly elected, we must distinguish between independence from the politicians and from the voters. In our earlier analysis this did not matter. The LDP was the majority party because it advocated the policies supported by a majority of the voters, so the voters and the LDP would have the same preferences about judicial behavior. This would even extend to wishing judges to make electioneering difficult for minor parties and to not minding judicial injunctions against locally elected politicians. Voters from the minor parties are a minority, and often the enjoined local politicians are from places with minority preferences - the mayor of a Socialist town in an LDP nation. Similarly, in the United States when the President appoints and the Senate confirms judges, they are reflecting the desires of their constituents. 
There is a difference, however, between electing a governor who appoints judges, the system in some states, and electing a governor and judges in the same election but by checking different boxes on a ballot. When judges are appointed, the voter must make a bundled choice: he cannot vote for the Republican governor and the Democrat judge. The same goes for retention. If the governor has the power to reappoint a judge or not, then the voters have bundled that power together with other gubernatorial powers, and in voting for a judge are also voting for retaining judges based on how much they please the governor.

What determines how a state bundles the voters' choice possibilities? This of course applies more widely than just to judges and governors. A democracy could vote for just one executive, who would appoint everyone else in the executive branch, or it could vote for every employee separately, all the way down to whoever takes out the trash. The basic tradeoff is between minimizing the information the voter needs to decide how to vote, which is done by having fewer elected offices, and reducing the power of the executive, which is done by having more elected offices.

Voters would like the executive to have more power if he will use it to carry out the policies for which they elect him. They face the problem, however, that once elected he may use the power for personal ends - such things as acquiring wealth, helping friends, or insulating hiimself from the possibility of electoral defeat. Unbundling power helps solve that problem by diversifying the voters' portfolio of policy providers, and by introducing "checks and balances" -- the ability of different officials to monitor each other without fear of being fired and in some cases the need for several to agree before new laws can be promulgated. Thus, having judges elected separately from governors means that if the governor fails to carry out the laws which he passes, the judges can force him to do so, and if he embezzles from the state treasury and shows up in court, he will be convicted.

F. Andrew Hanssen (2001) has made an admirable start at untangling the institutional structure of the state courts. Using regression methods, he finds that partisan elections are associated with the strength of the ruling party. The "merit plan", in which politicians (usually the governor) appoint judges from a list compiled by a nonpartisan nominating commission and the judge keeps his job if he wins an uncontested retention election, is inversely associated with the strength of the ruling party. These results accord with the repeated-game theory. Focus on the retention method in each case. The futures of judges who must face the voters in partisan elections are certainly dependent on the voters, but they are also dependent on the politicians who influence party endorsements, so partisan elections make for less independent judges. Judges under the merit plan are more independent. They must win appointment by finding favor from the nominating commission and the politician who makes the actual appointment, to be sure, but what matters more is the retention method. Since it is a nonpartisan election, without opposing candidates, it is very difficult to unseat such a judge, and politicians cannot intervene in the election by promoting rival candidates or withholding endorsements. Thus, Hanssen's results support the theory that where rival parties alternate in power they agree to insulate the judiciary from pressure by whichever party happens to be in power.

Why are U.S. federal judges appointed for life terms rather than having to face retention elections? Part of the answer is historical; for whatever reason, amending the U.S. Constitution has been much more difficult than amending state constitutions, so unless the voters thought retention elections were clearly superior, it would not be worth the cost of changing the institution. More practically, however, one of the main functions of the federal court system is to protect federal interests from state interference. If U.S. district judges were subject to retention 
votes from the people of their districts, it would be hard for them to make rulings that were in accord with the national majority of voters but opposed by the local district majority. It would be impractical, however, to hold retention elections in which every citizen of the United States voted for every judge. Only at the Supreme Court level would such a system potentially be useful.

\section{Judges and Bureaucrats}

Our second comparative puzzle is why judges are treated differently from other bureaucrats. Most government employees are in situations more like imperial Japan than either modern Japan or the United States. They are subject to the direct commands of the politicians, who can order them to change their decisions in particular cases. And the politician can control promotion. The bureaucrats may, of course, object that the politicians' orders are illegal, but their recourse is the same as that of any citizen: to go to the courts. The politicians are, after all, their bosses.

In modern Japan, the bureaucracy contains a large fast-track made up of bureaucrats with career tracks very similar to those of judges. The Level 1 Entrance Examination for the National Civil Service is ordinarily taken by students in their last year of college. In 1993, of 35,887 test-takers, 1,863 passed, a rate of 5.2 percent (Ikuta: 36). There were 1,012 entry positions, and the bureaus had already decided on many of the students they wanted, based on college performance, even before they passed the exam. Like judges, the successful test-takers are disproportionately from Tokyo and Kyoto Universities, and the Tokyo undergraduate program in law is particularly known as the place to be for a student aspiring to be an elite bureaucrat. Once the new graduate succeeds in getting a job, he ordinarily stays in one ministry for his entire career. Non-elite bureaucrats and those hired for their technical skills are regularly evaluated in compliance with National Personnel Authority Rule 10-2 if they are at or below the rank of division director, but the fast-trackers are subject only to informal, unwritten evaluation (Ikuta: 57). The successful young bureaucrat will rise from Officer to Senior Officer to Unit Chief to Assistant Director to Division Director, Deputy Director-General, Director-General, and Administrative Vice-Minister. Most will not make it to the pinnacle of Administrative ViceMinister, and most will retire around age 55 to take jobs in the private sector or quasigovernment agencies, a stage of life known as "descending from heaven" (amakudari). Like judges, elite bureaucrats are well paid - a director-general earns 1,230,000 yen per year (about $\$ 100,000)$ - but not nearly as well paid as their peers who went into the private sector out of college. $^{23}$

Thus, elite bureaucrats are much the same kind of people as elite judges--- and they are more than a cut above the ordinary Japanese politician in their educational background and intellectual ability. Some observers conclude that they are out of the control of the politicians,

\footnotetext{
${ }^{23}$ Ikuta (1995) is a good general guide to the civil service, as written by an experienced Japanese journalist. The National Personnel Authority's website, "Introduction to the Japanese Civil Service System," http://www.jinji.admix.go.jp/english/intro.htm (July 10, 2001), in both English and Japanese, provides details of procedures, ranks, and salaries, as well as data on such things as age at separation from the civil service. Two other entertaining sources of anecdotes are Jacob Schlesinger's 1997 Shadow Shoguns: The Rise and Fall of Japan's Postwar Machine, which centers on politicians, and Masao Miyamoto's rather naïve 1994 book, Straightjacket Society: An Insider's Irreverent View of Bureaucratic Japan.
} 
and that the bureaucrats are who really controls government policy in Japan. In an earlier chapter we quoted Chalmers Johnson, who said in what is the leading study of any Japanese ministry that the bureaucrats in the Ministry of International Trade \& Industry "make most major decisions, draft virtually all legislation, control the national budget, and [are] the source of all major policy innovations in the system" (1982: 20-21). James Q. Wilson said that, "in Japan, the bureaucracy is the government" (1989: 308). Tadehide Ikuta notes that ministers rarely if ever reject promotions put forward by the ministry officials, and concludes that: "The cabinet is practically a rubberstamp for nominees appointed by an agency's bureaucrats" (1995: 12). Karel van Wolferen admits that the politician has some leverage, but denies that it has any impact:

"Even if a minister uses all his remaining powers, it will not enable him in practice to redirect Japanese policy in any noticeable manner. A minister may have influence over a ministry in the sense that he can promote or fire officials, and exert leverage in the allocation of resources to benefit his supporters and constituency. But this is different from wielding strong political power over a bureaucracy. Except when it is part of a longstanding campaign to assert control over education, for example, a minister's 'policy-making' is generally too limited to deserve the name at all” (1989: 190).

Looking more closely, though, one sees that bureaucrats do seem to be responsive to the desires of politicians. We have mentioned that Ramseyer and Rosenbluth (1997: ch. 7) show that bureaucratic policymaking promotes the electoral objectives of the LDP; that McCubbins and Thies (1997) find that even shifts in the power of the different factions within the LDP result in changes in budget priorities; and that McCubbins and Noble (1995) show that the LDP keeps tabs on the political implications of what bureaucrats do and takes care to control the policy agenda. Yung Chul Park (1986: 61-77) explains in detail how politicians, particularly those in the LDP party committees ("tribes") created to monitor individual ministries, intervene in personnel policies, in particular.

Even writers who repeat the conventional wisdom that the bureaucrats are independent give evidence that this is not so. Van Wolferen tells us that Construction Ministry officials spend much of their time talking with politicians who want roads and such projects in their districts; that LDP member who intervene on behalf of city or prefectural governments for nationally-funded projects routinely are kicked back two percent of the project's value; and that the Tanaka political machine was able to leverage its commission for building contracts or regulatory changes to three percent of the value $(1989: 151,177)$. The politician may not even need to ask. Shortly after Takeshita became prime minister, almost all the building requests from his home prefecture of Shimane won approval, which is highly unusual. The governor of Shimane thanked the Construction Ministry for what he called a "congratulatory gift" to the new prime minister (1989: 156).

Ikuta recounts similar stories in his book on Japanese officialdom. Allowing contractors about to bid on a public project to meet and decide who will get which parts of the project and at what price (a practice so common it has its own name: dango), would seem to be contrary to the Antimonopoly Act, and, indeed, to be simple fraud. But high profits on construction projects are highly useful to politicians so long as contractors are appropriately grateful, and so prosecutors and the Fair Trade Commission rarely crack down (1995: 168). Legislation is indeed written by bureaucrats, proposed by the ministries, and is routinely passed by the Diet, but even after it has been modified within its originating ministry it must pass through the Cabinet Legislation Bureau, and "No agency reportedly has ever had a Cabinet order proposal 
forwarded to a Cabinet meeting in its original form" $(1995 ; 75)$. Pressure on the bureaucracy can even lead to suicide. After a high official in the Environment Agency committed suicide in 1990, an LDP Diet member said, "Mr. Yamauchi seemed fine; he smiled a lot. But the LDP was cruel to him; the party never listened to him yet made demand after demand while he was trying to give serious thought to the issues" (1995: 75).

Chapters 6 and 7 of Ramseyer and Rosenbluth collect a large number of similar anecdotes, from their own experience and from other works, as well as general analysis of how Japanese politicians control bureaucracies. One new agriculture minister started by saying in a speech to his bureaucrats, "It is said that art is long and life is short. You must think that 'agriculture lasts long and the minister's life is short.' You fellows don't last long either. My term is at most one year, but I can fire you through evaluations of your work performance. The truth is that 'agriculture is long and the bureaucrat's life is short' " (Park, 1986: 66 as cited in Ramseyer and Rosenbluth, 1997: 111). A MITI bureaucrat said, when asked why his ministry drafted futile statutes relaxing anti-collusion laws to rescue a textile industry doomed by international competition, "We know the industry won't last. We've known that for years. But in the meantime these textile firms use people who vote LDP. The party's got to be able to show them that it cares. So we do our part. We give the politicians a new statute to show the textile people every year" (Ramseyer and Rosenbluth, 1997: 121). MITI drafted the Large Stores Act in 1973, which authorized regulation to encourage the appropriate development of the retail industry, paying attention to the protection of consumer interests and guaranteeing the business opportunities of smaller retailers. ${ }^{24}$ After earlier regulation failed to do the trick, it came up with regulations that effectively required supermarkets to buy out the local retailers before they started building, reducing supermarket construction from 576 to 125 during the four years after 1979 (Ramseyer \& Rosenbluth: 1997:129-30). Small business support of the LDP was likely not coincidental; lack of protection of consumer interests was tangential. Ministry of Finance officials have been trying to consolidate the banking industry ever since the American Occupation, proposing statutes and engaging in jawboning to try to ease out the smaller and weaker banks that are most likely to cause headaches for regulators. They have consistently failed to get their bills passed, and the targeted banks, supporters of and supported by the LDP, found little to worry about. (Rosenbluth, 1989, summarized in Ramseyer and Rosenbluth, 1997: 126).

There are also stories of crackdowns on bureaucrats with the same flavor as those we related in Chapter 1 about judges. In 1953, shortly after the American Occupation ended, Shigeo Odachi, mayor of Singapore during the Japanese Occupation, became Education Minister. He brought along a number of officials from the pre-war bureaucracy who had been purged by the Americans, and a number of Education officials resigned in protest (van Wolferen: 101). In1962, Ichiro Kono became Minister of Construction. Saying that "there were no qualified personnel within the Ministry of Construction to choose from," he exercised his undoubted right to choose his own top officials and brought some in from the National Police Agency. He reportedly told Construction officials, "I don't give a damn what you have done before I came here. Stay if you want to work with me. Leave if you do not want to cooperate or are not competent for the job," provoking resignations (Ikuta: 107).

\footnotetext{
${ }^{24}$ Daikibo kouritenpo ni okeru kourigyo no jigyo katsudo no chosei ni kansuru horitsu (Law Concerning the Adjustment of Retail Business Operations in Large Retail Stores), Law NO. 109 of 1973. xxxx Mark, do you know how to add overlines for long vowels in Word?
} 
Are these anecdotes special cases in certain ministries, or are they just the tip of an iceberg of bureaucratic subservience? It would perhaps be more persuasive if we used our regression method to look at the relation between bureaucratic decisions and bureaucratic careers in the same way we did for judges. An effort to use statistical analysis would face a perhaps insurmountable problem, however. Judicial decisions are a very special sort of bureaucratic decision: public, sharp, attributable to a single panel of judges, and not circulated for comment before they are made. The end-product of other bureaucratic decisionmaking can be equally sharp and public - the road is built in Shimane or it is not-- but it is much harder for an outsider to know whether a bureaucrat's initial decision was reversed within the organization by other bureaucrats or politicians and to determine who is responsible for the ultimate decision. In the end, the voters say the politician is responsible. Thus, we will be content here to rely on the previous work for the premise that bureaucrats are not only not independent, but less independent than judges in modern Japan. ${ }^{25}$

Studies of U.S bureaucrats, notably Calvert, Moran, and Weingast (1987) have shown them to be similarly responsive to politicians. ${ }^{26}$ Granted, the top politicians rarely intervene in the bureaus directly. The general pattern is that the President (or Governor) appoints heads of bureaus and one or two layers of subordinates from outside the career bureaucracy, but the vast majority of the personnel are civil service employees, immune from firing for political reasons. Congress and the state legislatures have even less control, merely setting budgets and with the right, at most, to embarrass bureaucrats with public questioning. Yet the bureaucrats seem responsive not just to the President, but to Congress as well, an intricate dance when President and Congressmen are of different parties.

The reason for the combination of lack of firings or commands and bureaucratic responsiveness in the U.S. follows the Remains of the Day logic of butler and master described in Chapter 1: politicians do not need to intervene if the bureaucrats anticipate what they want. Knowing that politicians can intervene if necessary with outright reversal, reduced budgets, unpleasant job assignments, or even firings in extreme cases, bureaucrats administer according to the political preferences of the party in power -- and the politicians have no reason to

Imperial Japan's bureaucracy has received far less attention from scholars and popular

${ }^{25}$ It is perhaps worth mentioning one class of anecdote that seems to illustrate bureaucratic independence: the bureaucrat public prosecutors who pursue corruption cases against politicians. The most famous of these, the prosecution of former Prime Minister Tanaka for bribery by Lockheed, illustrates when prosecutors are likely to bring these cases. As Ikuta explains it (1995: 124-27), at the time of the arrest in 1976, Tanaka's rival within the LDP, Takeo Miki, was Prime Minister, and the Justice Minister was Osamu Inaba, of the rival Nakasone faction. Moreover, the Justice Department was having a hard time attracting recruits. In 1975, only 38 LRTI graduates had even applied for jobs as prosecutors, while the bureau considered 50 the minimum it needed to hire. In 1976, prosecutorial glamour having been restored, the number of applicants rose to 74. This illustrates two points: that the bureaucrats can sometimes do better by antagonizing current politicians than by supporting them, and that the incumbent party is not monolithic, but a coalition of politicians with often-diverging interests. As a postscript: Tanaka and his friends were more careful in who became Justice Minister over the next few years, new Justice Ministers and chief prosecutors belittled corruption probes, and between 1976 and 1992 not a single Diet member was arrested for corruption.

26 The empirical evidence is overwhelming: a few of the many studies include Calvert, Moran \& Weingast (1987), which looks at the response of American bureaucrats' behavior to changes in which politicians run the relevant Congressional committees, is just one of many empirical studies that confirm the responsiveness of the bureaucracy to the politicians. Others include Bagnoli \& McKee (1991); Coate, Higgins \& McChesney (1990); Weingast \& Moran (1983). 
writers than that of either modern Japan or the United States, but it requires discussion especially given that the Meiji oligarchs' theory of "transcendental government" meant to keep the executive branch, including the bureaucrats, independent of the politicians.

By the 1920's not only did the politicians control the Cabinet: they controlled the bureaus. Table 7-3 illustrates the ties between staff turnover and political control in two areas of the bureaucracy. Take Table 7-3A: changes in personnel at the Ministry of Home Affairs at the posts of section chief or higher each year. During the five years when the party controlling the Cabinet changed, an average of 79.4 people changed office. In the six years when the party did not change, an average of 35.2 people changed office. Whenever a Cabinet succeeded a rival party Cabinet, mid- and senior-level turnover doubled.

Similarly, take Table 7-3B: changes in the governorships. These posts too were under the Ministry of Home Affairs. On the two occasions when a Cabinet succeeded another Cabinet from the same party, the new Cabinet replaced almost no governors. When a Cabinet succeeded a rival party Cabinet, it immediately replaced almost all the governors.

Table 7-3: Personnel Changes in the Ministry of Home Affairs

A. Mid- and Senior-Level Personnel Turnover

\begin{tabular}{lll}
\hline Year & Cabinet Shift & Turnover \\
\hline 1921 & S to S & 13 \\
1922 & S to N & $51 *$ \\
1923 & N to N & 48 \\
1924 & N to N and N to K & $80 \star$ \\
1925 & None & 38 \\
1926 & K to K & 46 \\
1927 & K to S & $73 \star$ \\
1928 & None & 39 \\
1929 & S to M & $77 \star$ \\
1930 & None & 27 \\
1931 & M to S & $116 \star$ \\
\hline
\end{tabular}

B. Governorship Turnover (out of 45 governors)

\begin{tabular}{llll}
\hline Cabinet Date & Prime Minister & Party & Turnover \\
\hline June 11, 1924 & Kato & $\mathrm{K}$ & $27 \star$ \\
June 30, 1926 & Wakatsuki & $\mathrm{K}$ & 0 \\
April 20, 1927 & Tanaka & $\mathrm{S}$ & $40 *$ \\
July 2, 1929 & Hamaguchi & $\mathrm{M}$ & $35^{\star}$ \\
April 14, 1931 & Wakatsuki & $\mathrm{M}$ & 6 \\
December 13, 1931 & Inukai & $\mathrm{S}$ & $41^{\star}$
\end{tabular}


Notes: $\quad S$ is a Seiyukai Cabinet, $N$ is a nonparty Cabinet, $K$ is a Kenseikai Cabinet, and $\mathrm{M}$ is a Minseito Cabinet. Asterisks follow the numbers associated with changes in party.

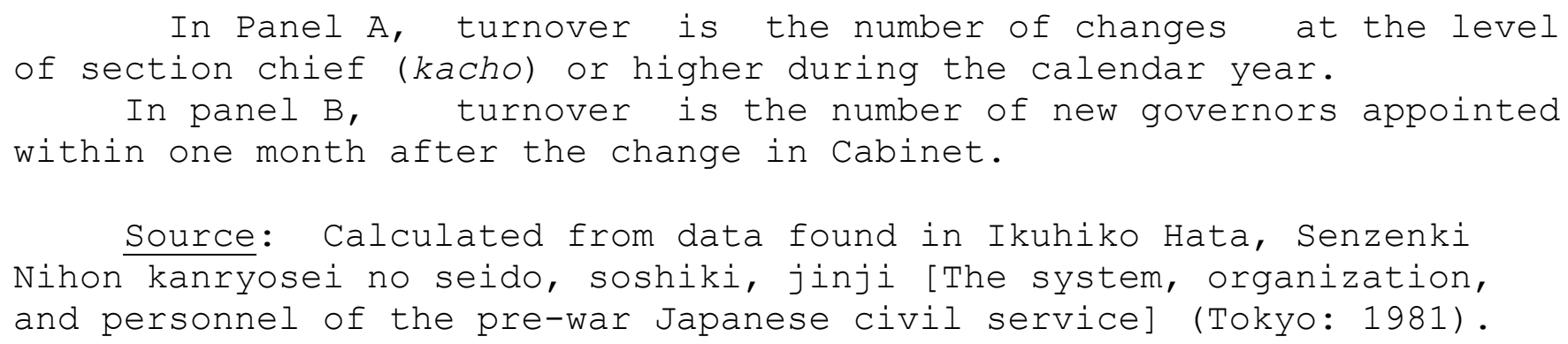

These data raise a further puzzle: why did the prewar Japanese politicians manipulate the bureaus earlier and more aggressively than the courts? The answer probably lies in electoral advantage. By the 1920s, party politicians realized that they were in an endgame and abandoned any cooperative strategies they might have played. Once they had decided to renege, however, they had to decide where to focus their resources. In order to decide what to manipulate to maximize their reelection chances, prewar politicians had first to decide which institutions would have the most immediate electoral effect.

In imperial Japan, the bureau with the most immediate electoral implications was the Ministry of Home Affairs. The Home Ministry, not the Justice Ministry, controlled the police, and the police supervised electoral campaigns. Through the police, the party in power could harass its opponents. Five days before the 1928 general election, the police had already filed electoral law charges against 638 people, and almost all were opposition party supporters (Tokyo Asahi Shimbun, Feb. 15, 1928). "The police only reported the actions of the parties out of power," one-time prime minister Takashi Hara (1965: 93; entry for 3/28/15) once observed. They largely "left the government party alone to do as it pleased."

Even if courts mattered in elections, they mattered less directly. As a result, party politicians did not begin to manipulate them until they had learned how to manipulate the more immediately relevant institutions. They had, after all, only recently taken control of the government. Before they could manipulate any government institution, they needed first to learn how it worked. Accordingly, they focused their resources first on the institutions with the greatest electoral impact. They turned to courts only later.

So it seems that in all three regimes we have been discussing, imperial Japan, modern Japan, and the United States, politicians control bureaucrats, even though the degree of judicial independence varied among the three regimes. Why would politicians in modern Japan and the United States wish to maintain institutions that control bureaucrats more tightly than judges? Above, we argued that in modern Japan the LDP gave considerable (if not complete) independence to judges to better provide voters with commitments to carry out the policies for 
which they were elected, intervening only indirectly via promotions and transfers, and then only after judges made decisions in certain categories of particular interest to the LDP politicians. For an alternating-party regime such as the United States, we argued that the two parties would like to adhere to an equilibrium in which the party in power refrains from changing the institutions of the judiciary to reduce its independence because it fears that if it does so, the rival party will use the judiciary against it when it next wins an election. But why not apply this logic to the bureaucracy too? Why wouldn't a loose rein (though not a nonexistent one) be better for inducing the bureaucracy to deliver the services voters want in Japan, and why in the United States does the party currently in power not fear that if it tells the bureaucrats what to do, the rival party will later do the same?

Return to our theory of judicial independence. It relies upon the short-term benefit $\mathrm{S}$ of political interference being less than the long-term cost L. There is certainly a short-term advantage $\mathrm{S}$ to the ruling party from controlling the bureaucrats. But is there a long-term cost $\mathrm{L}$ to depriving them of independence?

For judges, the two leading theories are the Landes-Posner theory of judges as promiseenforcers and the McCubbins-Schwartz theory of judges as bureaucrat-monitors. Neither of these applies to the bureaucracy. If there were no independent judiciary, the Landes-Posner theory would say that it would be desirable to have independent bureaucrats to enforce promises. But if a group of bureaucrats were carved off and given independence for this purpose, we would in effect have created an independent judiciary. The McCubbins-Schwartz theory applies even less. If bureaucrats are made independent, then nobody is monitoring them, so that cannot be the purpose of their independence. Both theories suggest that a nation starting with a nonindependent bureaucracy would like to carve off a certain part of it and make it into an independent judiciary, but neither suggests that the whole bureaucracy need be independent.

There exist, moreover, the straightforward reasons for keeping bureaucrats under the control of politicians that made it necessary to explain the independence of the judiciary in the first place. The voters elect politicians as their agents to produce new policies and administer existing government services. Independent bureaucrats would thwart this in two ways. First, they could substitute their personal policy preferences for those of the voters. Without the power to control the bureaucracy, the politicians could not control policy either. Second, the bureaucrats would lack incentives to administer either new or old policies effectively. Without the threat of personnel policy, why should a bureaucrat work hard? One might reply that someone controls promotions even in an independent bureaucracy, and merit would still be rewarded. But this logic has the flaw that the top bureaucrat lacks external incentives to take his monitoring responsibilities seriously It also takes us back to the first problem: the lower bureaucrats would be responsive to the top bureaucrats, not the voters, to the extent that they did exert effort on the job.

In contrast, there are good reason to keep bureaucrats under the control of the politicians. Any organization which people enter at a young age and remain in for most of their life will want to use promotions as a means of staffing high-level positions and of rewarding good performance in low-level positions Thus, to make the bureaucracy as free from political interference as the American judiciary would dramatically hamper its effectiveness. . But if promotions can occur, it must be at someone's discretion, and if anyone is to control the staff who carry out policy, why not the politicians? In a democracy they are accountable to those whom the policies are supposed 
to benefit, the voters, and so have incentive to work hard to make the organization effective at delivering services and legislation.

Even aside from the promise-enforcing and bureaucrat-monitoring functions of judges, the type of work that bureaucrats do makes direct control of them more important for everyday administrative efficiency. Bureaucrats make closed-door decisions with diffuse responsibility, whereas judges make public decisions attributable at least to a three-judge panel rather than to a ministry. A distant observer can detect misbehavior in a court proceeding, whereas detecting bureaucratic misbehavior requires observing the decision process as it unfolds behind the ministry doors. Bureaucratic decisionmaking is an example of the "teams" problem studied by Holmstrom (1982), in which individual efforts generate a group output and individual members can hide their shirking.

Bureaucrats also spend much of their time on simple administrative tasks, whereas judicial work is more technical. This means that the politician can better monitor bureaucrats if he is on the spot, even though more distant observation may have trouble allocating responsibility. He can tell if a memo briefing him for a conference is late or ill-written; he cannot tell whether a judicial opinion has failed to take into account everything it should. This reason applies more to low-level government employees than to Level I Examination elite bureaucrats, but the quality of even what high-level bureaucrats do is often easily observable, whereas even everyday court decisions are hard to make (after all, if the law and facts were clear, the parties would have settled out of court).

Perhaps the most important difference between what judges do and what other officials do is that the task of carrying out policies requires effort, whereas judges do not have to exert any more effort to carry out a policy than to block it - perhaps less, since blocking a policy usually requires more explanation. Since the bureaucrats must be made to exert effort, they must be given stronger incentives than judges to do their work.

This does raise the question, though, of whether it matters whether the politicians have the authority to reverse decisions and use personnel policy to punish bureaucrats. The politicians are outnumbered: there are far more unelected officials than elected officials. Moreover, most of the elected officials are in the legislative branch and in no position to exercise day-to-day authority even if they had it. It is no wonder that bureaucrats draft most legislation and make most decisions; the politicians are too few in number to physically do the job. And, as mentioned earlier, some may wonder if the politicians are up to the job mentally either: it is the bureaucrats who are the Tokyo University graduates, while the politicians, unless they are former bureaucrats, were more likely to have been in the 95 percent that failed the Level I Examination if they had bothered to take it at all.

The answer, of course, is that the politicians rely on a random sampling of decisions made by the bureaucrats, and their evaluation is based on results, which are generally simpler to evaluate than methods. Like the executives in large corporations, they set policy goals and then delegate authority to subordinates, often more technically adept, whose future careers are under their control. Chapter 6 of Ramseyer and Rosenbluth (1997) details the way that this is done in Japan - a method whose sophistication was raised to its highest level by Prime Minister Tanaka, a high-school dropout widely known for his ability to get things through the bureaucracy. As Tanaka put it, "Government officials are human computers; politicians set directions for them. ... At first you fight with the official, who typically responds with 'Why should I listen to you?' You then tell the official, It's government by party rule. When you become director-general, you 
will have use for me.' The official then will think about it, and come to his senses. The official will then come to you" (Ikuta, 1995: 109).

The politician needs two things to run a bureaucracy: incentives for the bureaucrat, and information on what the bureaucrat is doing. Career advancement and bureau budgets provide the typical incentives. In Japan, “descent from heaven" jobs provide another incentive. Typically, observers see these jobs as putting the bureaucracy under the control of the private sector. This neglects the fact that much of the usefulness of ex-bureaucrats derives from their contacts with their old bureau and the politicians who oversee it. If they have pleased the politicians, they will have good contacts and be helpful to their new employer; if they have displeased the politicians, it will be safer not to hire them - at least in a country like Japan, where the offended party will continue to be in power. This is of course even more true if the postretirement job is in a quasi-governmental organization or is election to the Diet - a not uncommon second career for elite bureaucrats. $^{27}$

As Ramseyer and Rosenbluth explain, the ex-bureaucrats in the Diet-and the current bureaucrats who are looking to promotion or good post-retirement jobs-also help the less experienced politicians acquire the information they need to monitor the bureaucracy. Information is a valuable commodity in bureaucracies, and if the politician has something with which to buy it - favor and promotions-- he will find bureaucrats willing to sell it. The transactions are not so crude, of course, but where gains from trade exist, we would expect trade to occur.

Even without information about bureaucratic disobedience being volunteered by other bureaucrats eager to please, however, the politician would not be totally in the dark. Hierarchies are set up in organizations so that the leader can limit his personal effort to monitoring his immediate subordinates. In this case, the politician can delegate monitoring to his immediate subordinates in the bureaucracy, letting them know what kinds of policies he wants to see, or even relying on their experience in knowing what politicians want. They, in turn, delegate monitoring to their own subordinates, using their own influence over promotions. For the politician, such a strategy is particularly feasible because it is the top bureaucrats whose promotions he can most easily influence and who, being older, are nearing the time when they hope to move into their high-profile post-retirement jobs.

Yet another source of information for the politician in charge of the bureau, and a very important one, is complaints from other politicians or voters. McCubbins and Schwartz (1984) explain how drastically this reduces the need for direct monitoring. Rather than examine every decision the bureaucrats make, the politician can wait for complaints from people whose interests he shares - his voters and politicians from his party. This is how even junior politicians outside a ministry also have influence. If the bureaucrat rejects the junior politician's request, he can appeal to the senior politician with formal authority over the bureaucrat, who will then investigate the decision. In modern Japan, the LDP's party oversight committees exist to aid this process. Backbenchers join committees that watch individual ministries carefully. If the backbenchers are unhappy with the shape legislation is taking, they can let the Minister and Prime Minister know. If all the politicians are in agreement, the bureaucrats responsible can be

\footnotetext{
27 An exception that proves the rule is the difficulty the Socialists had in their 9-month-long administration in 1947. Ministry of Finance official Takeo Fukuda could not find the funds for a sensitive program for the Socialists, but was more successful a few months later for the conservative government that succeeded them. He later resigned to become a leading LDP politician (Van Wolferen, 1989: 189). A government duraion known to be short will have difficulty in using bureaucrats for partisan purposes.
} 
directed to change what they are doing. Otherwise, the discussion becomes an element in the intricate process by which backbenchers choose prime ministers and prime ministers choose ministers.

Thus, it is both desirable and feasible for politicians to control bureaucrats, and if their control is tight enough, we will never observe bureaucrats doing anything the politicians do not want. Indeed, we will often see the bureaucrats anticipating the desires of the politicians, making proposals that the politicians like but would never have thought of on their own. Such bureaucratic initiative is a sign of effective control, not lack of control. It is only when bureaucrats are unsure of what politicians want (as in transitions from one party to another, when the party changes policies suddenly, or when there is intra-party dissension) that we will observe bureaucrats making decisions the majority party does not want. The bureaucrats will be accountable to the politicians, and the politicians will be accountable to the voters. ${ }^{28}$

An alternative institution to attain this end would be to elect the bureaucrats, which would seem to retain accountability to the voter and make it more direct. Why have any middleman between the voter and his public servant? We earlier discussed unbundling the electoral package of governor and supreme court judges in U.S. states. Why not unbundled the package of governor and administrators, voting separately for each office, all the way down to the janitor who cleans the governor's office? This seems absurd - and it is absurd, but why? The response that immediately comes to mind-that there is a practical difficulty in voting for hundreds of offices - is not the main problem. It is not hard to set up a voting machine so that voters can vote for a straight party ticket with the exception of particular offices they care about. This saves the typical voter from having to puzzle over who to support for local coroner or state comptroller. It also points to one big problem with voting for minor officials: the swing votes will come from those voters who take a special interest in that official, and those are going to be the ones whose interests he affects. In such a situation, we would expect the good of the average voter to be sacrificed to the good of the informed voter. ${ }^{29}$

Another reason to package governor and lower official together is to avoid divided responsibility. If they are elected separately, then after a project fails the governor can point the voters towards the official, while the official will suggest that the governor is to blame. Since voters will suspect both, they both will share the penalty, and this gives neither one the efficient incentive to put forth his best effort. This is another example of the "teams" problem alluded to earlier in this chapter (Holmstrom, 1982). If, on the other hand, only the governor is elected and the bureaucracy is not independent, the voters will always blame the governor: either he made the mistake himself, or he failed by not properly controlling the lower official.

Both of these reasons point to a paradox: when too many officials are accountable at the

\footnotetext{
${ }^{28}$ For a book-length treatment of comparative government institutions as solutions to this kind of agency problem, see Cooter (2000). His more abstract treatment draws out more implications; e.g., that if there is sufficiently high probability that mere bad luck will make bureaucratic behavior come to light, the politician will give him wider discretion ex ante (p. 86).

${ }^{29}$ Having the governor appoint the official does not completely solve the problem. It remains the case that those voters who are particularly affected by the official will be the ones whose vote for governor will turn on his appointment of that official. If the governor knows this, his appointment will be influenced by the desire of the special interest. Having the governor in between, however, hinders the special interest from making so easy use of its votes, because it must obtain access to the governor, who is busy with a great many lobbying requests, to let him know of their interest in that official.
} 
ballot box, none of them is as accountable as when only one official is up for a vote. It is simply too costly for voters to keep track of all the officials, and so they delegate their authority to one, and keep a close watch on him. It is like the response to the proverb that your should not put all your eggs in one basket: that you should indeed put all your eggs in one basket--- and watch that basket.

This discussion of electing bureaucrats may seem too theoretical, far from the practice of any real-world country. American readers, though, will realize that it is not. A federalist system such as that of the United States does not usually have voters electing both an executive and his subordinates (though there usually are separate elections for governor and for other high state officials such as the secretary of state and attorney-general). It does, however, have multiple hierarchies. Many Americans will vote for a president of the country, a governor of the state, a commissioner of the county, and a mayor of the city in which he lives Some services, such as crime prevention and detection, will be provided at all four levels. Others will not - it can happen that only the country runs the army, only the state runs universities, only the county runs the library, and only the city runs liquor licensing - but the voter must keep track of the talents of four executives, not to mention the four legislative bodies associated with them. The reason is no doubt connected to the one standardly given: that different localities want different services, and so liquor licensing in Bloomington is unbundled from liquor licensing in Cambridge. But this logic does not explain Japan, where school textbooks are an issue for the prime minister, ${ }^{30}$ nor does it explain why other countries besides Japan and the United States have even more centralized and bundled governments. Indeed, viewing just the Japanese case, one might explain the bundling there as the result of regional differences too: if majority voters think that majorities in atypical localities such as left-wing Kyoto would use federalism to promote atypical policies there, they would vote against regional unbundling. And, in any case, we are left wondering why centrally elected officials could not administer heterogenous local rules, instead of having to elect local officials for local rules. The question of which bureaucrats are bundled is both practical and interesting — but too hard for us to fully address here. ${ }^{31}$

One detail of the puzzle remains. We have seen that it is useful for politicians to be able to discipline bureaucrats, and that as in private corporations, politicians make use of hierarchies to monitor their subordinates. In private corporations, however, the board of directors allows the chief executive to fire his subordinates at will. Why, then, do governments use civil service systems in which firing is difficult even if promotions and transfers can still be used for discipline?

The answer is not the conventional one that a civil service system eliminates political influence on the bureaucracy. It does not, since politicians can still intervene directly to change decisions and can still affect personnel policy, even if they cannot take away a bureaucrat's salary. And as we have explained, eliminating political influence would be undesirable, because it would prevent the officials elected by the voters from delivering the policies the voters want.

\footnotetext{
${ }^{30}$ China and South Korea objected to the treatment of prewar Japanese wrongs in the textbooks approved for Japanese schools and this became a national Japanese issue. See, for example, Kiroku Hannai, "Textbook Criticism Right on Target," The Japan Times Online, June 25, 2001, http://www,japantimes.co.jp (viewed July 20, 2001).

${ }^{31}$ The classic work on federalism from a public choice perspective is William Riker's 1964 book, Federalism: Origins, Operation, Significance. For a more recent treatment by a leading economist, see Chapters 5 and 6 of Cooter's 2000 book, The Strategic Constitution. It is clear that sometimes it is desirable to have local regulations because local conditions differ. The harder question that is why a central government administering heterogeneous local rules is not better than a variety of local governments.
} 
Rather, the usefulness of the civil service system is that it forces the politicians to use the bureaucracy solely as a means of delivering services rather than as a way to reward supporters. This is particularly important because giving supporters jobs is generally an inefficient way to channel wealth to them. Someone who wants a reward for political support is unlikely to have the talents and skills appropriate to the bureaucratic post that available. A ward chairman may be fine as a general manager, but the bureaucracy needs accountants and computer programmers too. The politicians will not put incompetents in all the posts, since they must deliver services to voters as well as please special supporters, but the presence of political deadwood will degrade the quality of services and raise their cost. Also, if political changes lead to turnover in jobs (admittedly, more of a problem in an alternating-party regime like the US than in a single-party regime like Japan), the politically appointed bureaucrats will never learn the jobs properly and will perpetually be in end-periods, untrustworthy because they expect to be moving on soon anyway. Thus it makes sense for voters to support politicians who agree to install a civil service system to restrict the amount of employment patronage available. And in an alternating-party regime, the politicians might favor a civil service even without voter pressure, because they know it is costly in terms of efficiency and it benefits the other party as much as themselves. 


\section{Conclusion}

Judicial independence is not primarily a matter of constitutional text. Both the modern Japanese and the modern American constitutions purport to insulate judges from political leaders. Yet modern American politicians insulate their judges, while Japanese politicians do not. American politicians appoint party loyalists, but once they appoint them intervene no further. Japanese politicians intervene regularly to ensure that their judges stay loyal. American politicians could restructure their courts to enable them to intervene as Japanese politicians do. Notwithstanding, they do not.

Instead, whether politicians intervene in the courts seems a function of electoral exigency. Although both American and Japanese political leaders must compete in electoral markets, LDP leaders competed far more successfully than the leaders of either the Democratic or the Republican parties. As a result, LDP leaders had better odds of retaining control. Having better odds, they faced lower risk-adjusted costs to nonindependent judiciaries. With lower costs, they opted for nonindependent judges and closely monitored their judicial agents.

Independent courts represent a cooperative equilibrium to a game that closely resembles an indefinitely repeated Prisoner's Dilemma. As such, they represent one outcome -- but not a unique one. In indefinitely repeated Prisoner's Dilemmas, a wide range of outcomes can be equilibria. Only if a repeated Prisoner's Dilemma is about to end do the outcomes become more predictable. Where one party expects to win elections consistently, it may well decide not to keep courts independent. Where both parties expect the electoral market to end soon, they will not keep courts independent. Landes and Posner nicely captured the electoral logic behind the American judicial system. In doing so, however, they captured a special case -- a result peculiar to electoral markets where all parties perform erratically. Here, we generalize the theory to a broader range of competitive electoral markets.

The theory would seem to apply to bureaucrats as well as judges, yet bureaucrats lack independence in all three regimes that we consider, regardless of the degree of interparty competition or the approach of an end period We conclude that this is because the benefits of independence - the enforcing of promises made by the politicians and the monitoring of bureaucrats - are benefits that can be gained by making only a small number of government personnel independent, and the costs - reduced accountability to the electorate in policy decisions and reduced incentives for quality effort - are lower for the tasks that judges perform.

Potentially, the 50 American states present a more systematic test of the theory. The various states maintain courts with a wide range of institutional independence. In some states, politicians and voters keep close control over judicial careers; in others, they offer judges an independence akin to that of federal judges. Over the past century, the fifty states have also presented electoral markets with a wide range of political variability. In some states, one party maintained a lock on power for decades; elsewhere, the parties alternated regularly in office. The theory above suggests (a) that states with alternating parties may or may not maintain independent courts but (b) that states where one party regularly wins elections will be less likely to maintain independent courts.

We have not performed that systematic test. Instead, we offer here a more modest argument -- one with three archetypal examples. In the modern United States, neither party controls either the legislature or the presidency. The parties maintain a strict hands-off-thecourts rule. In postwar Japan, one party dominated the electoral market. It consistently offered nonindependent courts. In prewar Japan, both parties knew that the military would likely usurp 
government soon. They too eventually offered nonindependent courts. Despite most of what is taught in law schools, judicial independence has had less to do with constitutional texts. It has had more to do with elections. 


\title{
Appendix: Constitutional Texts
}

\author{
Japanese Postwar Constitution
}

Excerpt from CHAPTER V: THE DIET

Article 64:

The Diet shall set up an impeachment court from among the members of both Houses for the purposes of trying those judges against whom removal proceedings have been instituted. 2) Matters relating to impeachment shall be provided for by law.

\section{CHAPTER VI: JUDICIARY}

Article 76:

The whole judicial power is vested in a Supreme Court and in such inferior courts as are established by law. 2) No extraordinary tribunal shall be established, nor shall any organ or agency of the Executive be given final judicial power. 3) All judges shall be independent in the exercise of their conscience and shall be bound only by this Constitution and the laws.

\section{Article 77:}

The Supreme Court is vested with the rule-making power under which it determines the rules of procedure and of practice, and of matters relating to attorneys, the internal discipline of the courts and the administration of judicial affairs. 2) Public procurators shall be subject to the rule-making power of the Supreme Court. 3) The Supreme Court may delegate the power to make rules for inferior courts to such courts.

\section{Article 78:}

Judges shall not be removed except by public impeachment unless judicially declared mentally or physically incompetent to perform official duties. No disciplinary action against judges shall be administered by any executive organ or agency.

\section{Article 79:}

The Supreme Court shall consist of a Chief Judge and such number of judges as may be determined by law; all such judges excepting the Chief Judge shall be appointed by the

Cabinet. 2) The appointment of the judges of the Supreme Court shall be reviewed by the people at the first general election of members of the House of Representatives following their appointment, and shall be reviewed again at the first general election of members of the House of Representatives after a lapse of ten(10) years, and in the same manner thereafter.

\section{Article 80:}

The judges of the inferior courts shall be appointed by the Cabinet from a list of persons nominated by the Supreme Court. All such judges shall hold office for a term of ten(10) years with privilege of reappointment, provided that they shall be retired upon the attainment of the age as fixed by law. 2) The judges of the inferior courts shall receive, at regular stated intervals, adequate compensation which shall not be decreased during their terms of office.

\section{Article 81:}

The Supreme Court is the court of last resort with power to determine the constitutionality of any law, order, regulation or official act.

Article 82: 
Trials shall be conducted and judgement declared publicly. 2) Where a court unanimously determines publicity to be dangerous to public order or morals, a trial may be conducted privately, but trials of political offenses, offenses involving the press or cases wherein the rights of people as guaranteed in CHAPTER III of this Constitution are in question shall always be conducted publicly.

JAPAN: THE 1889 MEIJI CONSTITUTION

\section{CHAPTER V. THE JUDICATURE}

Article 57. The Judicature shall be exercised by the Courts of Law according to law, in the name of the Emperor. (2) The organization of the Courts of Law shall be determined by law.

Article 58. The judges shall be appointed from among those who possess proper qualifications according to law.

(2) No judge shall be deprived of his position, unless by way of criminal sentence or disciplinary punishment.

(3) Rules for disciplinary punishment shall be determined by law.

Article 59. Trials and judgments of a Court shall be conducted publicly. When, however, there exists any fear, that such publicity may be prejudicial to peace and order, or to the maintenance of public morality, the public trial may be suspended by provisions of law or by the decision of the Court of Law.

Article 60 . All matters that fall within the competency of a special Court, shall be specially provided for by law.

Article 61. No suit at law, which relates to rights alleged to have been infringed by the illegal measures of the administrative authorities, and which shall come within the competency of the Court of Administrative Litigation specially established by law, shall be taken cognizance of by Court of Law.

http://uiarchive.uiuc.edu/mirrors/ftp/ibiblio.unc.edu/pub/docs/books/gutenberg/etext96/cjold10.txt (July 23, 2001)

\section{UNITED STATES: 1789 CONSTITUTION}

\section{Article I.}

Excerpt from Section 2:

The House of Representatives shall chuse their Speaker and other Officers; and shall have the sole Power of Impeachment.

\section{Excerpt from Section 3:}

The Senate shall have the sole Power to try all Impeachments. When sitting for that Purpose, they shall be on Oath or Affirmation. When the President of the United States is tried, the Chief Justice shall preside: And no Person shall be convicted without the Concurrence of two thirds of the Members present.

Judgment in Cases of Impeachment shall not extend further than to removal from Office, and disqualification to hold and enjoy any Office of honor, Trust or Profit under the United States: but the Party convicted shall nevertheless be liable and subject to Indictment, Trial, Judgment and Punishment, according to Law.

Article. III.

Section. 1. The judicial Power of the United States shall be vested in one supreme Court, and in such inferior Courts as the Congress may from time to time ordain and establish. The Judges, both of the supreme and inferior Courts, 
shall hold their Offices during good Behaviour, and shall, at stated Times, receive for their Services a Compensation, which shall not be diminished during their Continuance in Office.

Section. 2. The judicial Power shall extend to all Cases, in Law and Equity, arising under this Constitution, the Laws of the United States, and Treaties made, or which shall be made, under their Authority;--to all Cases affecting Ambassadors, other public Ministers and Consuls;--to all Cases of admiralty and maritime Jurisdiction;--to Controversies to which the United States shall be a Party;--to Controversies between two or more States;--between a State and Citizens of another State [Modified by Amendment XI];--between Citizens of different States;--between Citizens of the same State claiming Lands under Grants of different States, and between a State, or the Citizens thereof, and foreign States, Citizens or Subjects.

In all Cases affecting Ambassadors, other public Ministers and Consuls, and those in which a State shall be Party, the supreme Court shall have original Jurisdiction. In all the other Cases before mentioned, the supreme Court shall have appellate Jurisdiction, both as to Law and Fact, with such Exceptions, and under such Regulations as the Congress shall make.

The Trial of all Crimes, except in Cases of Impeachment, shall be by Jury; and such Trial shall be held in the State where the said Crimes shall have been committed; but when not committed within any State, the Trial shall be at such Place or Places as the Congress may by Law have directed.

Section. 3. Treason against the United States shall consist only in levying War against them, or in adhering to their Enemies, giving them Aid and Comfort. No Person shall be convicted of Treason unless on the Testimony of two Witnesses to the same overt Act, or on Confession in open Court.

The Congress shall have Power to declare the Punishment of Treason, but no Attainder of Treason shall work Corruption of Blood, or Forfeiture except during the Life of the Person attainted. 


\section{References}

(I apologize for the peculiar formatting of these references. I am inexpert in WORD, and when I excerpted these from the bibliography of the book to which this paper is a chapter, the formatting changed in odd, unsystematic ways. We'll have it fixed up in the book.

Anderson, Gary, William Shughart, and Robert Tollison (1989) "On the Incentive of Judges to Enforce Legislative Wealth Transfers," 32 Journal of Law and Economics 215-28 (April 1989).

Bagnoli, Mark \& Michael McKee (1991) “Controlling the Game: Political Sponsors and Bureaus," 7 Journal of Law, Economics, and Organization 229-47 (Fall 1991).

Block, Stewart A. 1970. "The Limitations of Article 111 on the Proposed Judicial

Removal Machinery: S. 1506,” 118 University of Pennsylvania Law Review 1064.

Buckley, Frank \& Eric Rasmusen. 2000. "The Uneasy Case for the Flat Tax," 11

Constitutional Political Economy 295-318 (December 2000).

Calder, Kent E. 1988. Crisis and Compensation: Public Policy and Political Stability in Japan. Princeton: Princeton Univ. Press.

Choper, Jesse H. 1974. “The Supreme Court and the Political Branches: Democratic Theory and Practice," 122 University of Pennsylvania Law Review 810.

Coate, Malcolm B., Richard S. Higgins, \& Fred S. McChesney (1990) "Bureaucracy and Politics in ETC Merger Challenges," 33 Journal of Law \& Economics 463-82 (October 1990).

Cohen, Mark A. (1991) 'Explaining Judicial Behavior or What's 'Unconstitutional'

about the Sentencing Commission," 7 Journal of Law, Economics \& Organization 183-99

(Spring 1991).

Cohen, Mark A. 1992. "The Motives of Judges: Empirical Evidence from Antitrust Sentencing," 12 International Review of Law \& Economics 13.

De Figueiredo, John M. and Emerson H. Tiller. 1996. "Congressional Control of the Courts: A Theoretical and Empirical Analysis of Expansion of the Federal Judiciary," 39 Journal of Law and Economics 435-62 (October 1996). 
Ellis, Richard E. 1971. The Jeffersonian Crisis: Courts and Politics in the Young

Republic.

Freund, Paul A. 1988. “Appointment of Justices: Some Historical Perspectives, 101 Harvard Law Review 1146-xxx.

Fudenberg, Drew, \& Eric Maskin. 1986. "The Folk Theorem in Repeated Games with Discounting or with Incomplete Information," 54 Econometrica 533-xxx.

Hanssen, F. Andrew. 2001. "Is there an Optimal Level of Judicial Independence?” working paper, Montana State University, Dept. of Agricultural Economics and Economics, Bozeman, Montana.

Hara, Takashi. 1965. Hara Takashi nikki [Diary of Hara Takashi]. Tokyo:xxx .

Haskins, George Lee, \& Herbert A. Johnson. 1981. History of the Supreme Court of the United States.

Hata, Ikuhiko. 1981. Senzenki Nihon kanryosei no seido, soshiki, jinji [The System, Organization, and Personnel of the Pre-war Japanese Civil Service]. Tokyo.

Ikuta, Tadahide. 1995. Kanryo: Japan's Hidden Government. Hideo Yanai, translator. Tokyo: NHK Publishing.

Johnson, Chalmers. 1982. xxx

Johnson, David Ted. 1996. The Japanese Way of Justice: Prosecuting Crime in Japan. (Ph.D. Dissertation, Jurisprudence \& Social Policy, University of California, Berkeley).

Johnson, Ronald N. and Gary D. Libecap. 1994. The Federal Civil Service System and the Problem of Bureaucracy: The Economics and Politics of Institutional Change. Cambridge: National Bureau of Economic Research.

Kreps, David, Paul Milgrom, John Roberts, \& Robert Wilson. 1982. "Rational Cooperation in the Finitely Repeated Prisoners' Dilemma,” 27 Journal of Economic Theory 245-52.

Landes, William M. \& Richard A. Posner. 1975. "The Independent Judiciary in an InterestGroup Perspective,” 18 Journal of Law \& Economics 875-901 (December 1975).

Manchester, William (1973) The Glory and the Dream: A Narrative History of the United States 1932-1972, Boston: Little, Brown, and Company (1973).

Mason, Alpheus Thomas. 1937. "Politics and the Supreme Court: President Roosevelt's Proposal," 85 University of Pennsylvania Law Review 659-xxx. 
McCubbins, Mathew D. \& Thomas Schwartz. 1984. "Congressional Oversight Overlooked: Police Patrols versus Fire Alarms,” 28 American Journal of Political Science 165-79.

Mitani, Taichiro. 1988. "The Establishment of Party Cabinets, 1898-1932," in Peter Duus, editor, The Cambridge History of Japan, Vol 6: The Twentieth Century. Cambridge: Cambridge University Press, 1988.

Miyamoto, Masao. 1995. Straightjacket Society: An Insider's Irreverent View of Bureaucratic Japan. Tokyo: Kodansha International.

Moe, Terry M. 1991. "Politics and the Theory of Organization," 7 Journal of Law Economics \& Organization 106-29 (Spec. Issue).

Nihon minshu horitsuka kyokai, ed. 1990. Zen Saibankan keireki soran: kaitei shinban [Biographical Information on All Judges: New Revised Edition]. Tokyo: Konin sha (ZSKS)

Posner, Richard A. 1985. The Federal Courts: Crisis and Reform. Cambridge:

Harvard University Press.

Ramseyer, J. Mark. 1994. "The Puzzling (In)dependence of Courts: A Comparative Approach," 23 J. Legal Stud. 721-48 (June).

Ramseyer, J. Mark \& Eric B. Rasmusen. 1997. "Judicial Independence in a Civil Law Regime: The Evidence from Japan," 13 Journal of Law, Economics \& Organization 259-86 (October 1997).

Ramseyer, J. Mark \& Eric B. Rasmusen. 1999. "Why the Japanese Taxpayer Always Loses," 72 Southern California Law Review 571-96. (January/March 1999).

Ramseyer, J. Mark \& Eric B. Rasmusen. 2000. "Skewed Incentives: Paying for Politics as a Japanese Judge," 83 Judicature, 190-95 (Jan.-Feb. 2000).

Ramseyer, J. Mark \& Eric B. Rasmusen. 2001a. "Why is the Japanese Conviction Rate so High," 30 Journal of Legal Studies 53-88 (January 2001).

Ramseyer, J. Mark \& Eric B. Rasmusen. 2001b. "Why Are Japanese Judges so Conservative in Politically Charged Cases?" xxx American Political Science Review xx (June 2001).

Ramseyer, J. Mark \& Frances McCall Rosenbluth. 1993. Japan's Political Marketplace, Cambridge: Harvard University Press. New edition, 1997.

Ramseyer, J. Mark, \& Frances McCall Rosenbluth. 1995. The Politics of Oligarchy: Institutional Choice in Imperial Japan. Cambridge: Cambridge University Press. 
Rasmusen, Eric B. 1994. "Judicial Legitimacy as a Repeated Game," 10 Journal of Law, Economics \& Organization 62-83 (April 1994).

Rasmusen, Eric B. 2001. Games and Information: An Introduction to Game Theory, $3^{\text {rd }}$ edition ( $1^{\text {st }}$ edition 1989) Oxford: Basil Blackwell.

Riker, William. 1964. Federalism: Origins, Operation, Significance. Boston: Little, Brown and Company.

Rosenbluth, Frances McCall, 1989. Financial Politics in Contemporary Japan. Ithaca: Cornell University Press.

Selten, Reinhard. 1978. "The Chainstore Paradox," 9 Theory \& Decision 127.

Shartel, Burke 1930. "Federal Judges_-Appointment, Supervision, and Removal—Some Possibilities under the Constitution, 28 Michigan Law Review 870.

Spiller, Pablo T. \& Rafael Gely. 1992. "Congressional Control or Judicial Independence: The Determinants of U.S. Supreme Court Labor-Relations Decisions, 1949--1988," 23 RAND Journal of Economics 463-92.

Stephenson, Matthew. 2001. "When the Devil Turns: The Political Foundations of

Independent Judicial Review,” Unpublished paper, Dept. of Government, Harvard University, Cambridge, Mass.

Story, Joseph. 1833. Commentaries on the Constitution of the United States. Xxx: Xxx.

Surrency, Erwin C. 1967. "The Courts in the American Colonies," 11 American Journal of Legal History 347.

Toma, Eugenia Froedge. 1991. "Congressional Influence and the Supreme Court: The Budget as a Signalling Device," 20 Journal of Legal Studies 131-46 (January 1991).

Turner, Kathryn. 1961. "The Midnight Judges," 109 University of Pennsylvania Law Review 494.

van Wolferen, Karel. 1989. The Enigma of Japanese Power. New York: Alfred A. Knopf.

Weingast, Barry R. \& Mark J. Moran. 1983. "Bureaucratic Discretion or Congressional Control? Regulatory Policymaking by the FTC," 91 Journal of Political Economy 765.

Williamson, Oliver E. 1993. "Transaction Cost Economics and Organization Theory," 2 Industrial \& Corp. Change 107.

Wilson, James Q. 1989. Bureaucracy: What Government Agencies Do and Why They Do It. New York: Basic Books. 
ZSKS. See Nihon minshu. 